

IMF Working Paper

\title{
What Shapes Current Account Adjustment During \\ Recessions?
}

by Christina Kolerus

IMF Working Papers describe research in progress by the author(s) and are published to elicit comments and to encourage debate. The views expressed in IMF Working Papers are those of the author(s) and do not necessarily represent the views of the IMF, its Executive Board, or IMF management. 


\title{
IMF Working Paper
}

Research Department

\section{What Shapes Current Account Adjustment During Recessions? Prepared by Christina Kolerus ${ }^{1}$}

Authorized for distribution by Daniel Leigh

July 2021

\section{IMF Working Papers describe research in progress by the author(s) and are published to elicit comments and to encourage debate. The views expressed in IMF Working Papers are those of the author(s) and do not necessarily represent the views of the IMF, its Executive Board, or IMF management.}

\begin{abstract}
This paper studies the dynamics of external accounts during 278 economic recession events in the past 60 years and sheds light on key factors that shape these patterns. Economic recessions trigger highly-persistent increases in the current account, driven by an initial, sharp decline in investment and fueled by medium term deleveraging, more so in advanced economies than in emerging markets. The strengthening of the current account is more pronounced when internal and external imbalances are present, and less when recessions are synchronized across countries. During severe natural disasters or epidemics, however, current accounts tend to weaken in the short term. Consistent with these findings, the COVID-19 shock, with comparatively moderate pre-existing imbalances yet high synchronization, had a muted effect on current account balances. The compositional changes, however, were unique and driven by unprecedented policy intervention, with record public dissaving more than offsetting exceptional private saving.
\end{abstract}

JEL Classification Numbers: F14, F32, G01

Keywords: Current account, saving-investment balance, recessions, external crises Author's E-Mail Address: ckolerus@imf.org

\footnotetext{
${ }^{1}$ I would like to thank Daniel Leigh and Gustavo Adler for many helpful discussions and guidance, Jair Rodriguez for excellent research assistance, and seminar participants at the IMF for useful comments.
} 
I. Introduction .$\underline{5}$



III. How do current account balances behave during recessions? ......................................10

Current Account Sensitivity to Recessions over Time ..............................12

Distribution of Impact .................................................................

Income Groups and Commodity Exporters ..............................................13

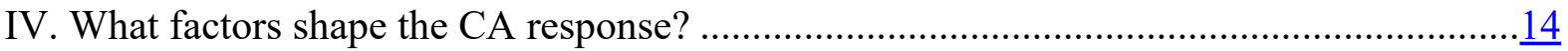

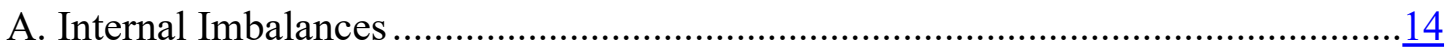

Credit Booms: CA Adjustment Through Falling Investment and Private

Deleveraging ................................................................................. 14

High Public Debt: CA Adjustment Reflects Rebuilding Fiscal Buffers in the $\underline{15}$

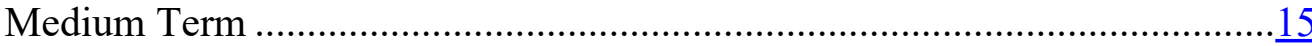

B. External Imbalances ..........................................................................

Sustained CA Deficits: CA Adjustment Through Private and Public

Deleveraging .17

Summarizing Imbalances.................................................................. 18

C. Globally Synchronized Recessions ............................................................. $\frac{19}{20}$

D. Natural Disasters and Epidemics ..............................................................

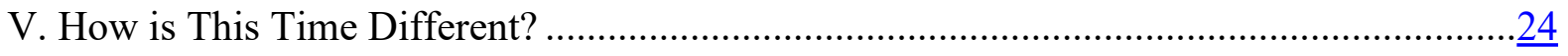

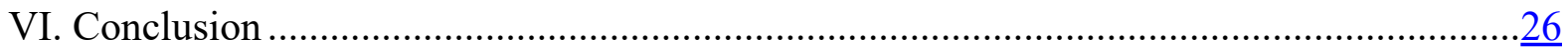

Tables

1. Current Account and Saving-Investment Balances with Internal Imbalances....................16

2. Combining Internal and External Imbalances......................................................... $\frac{18}{23}$

3. Determinants of External Adjustment ..............................................................23

Figures

1. Number of Countries in Recession, 1960-2019

2. Number of Countries in Recession by Income Group, 1960-2019 ................................... $\underline{8}$

3. Current Account Response to Recessions............................................................... $\frac{10}{10}$

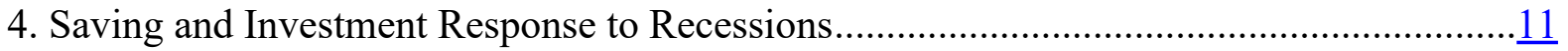

5. Trade and Exchange Rates Response to Recessions...................................................11

6. Current Account Sensitivity to Recessions over Time ................................................12

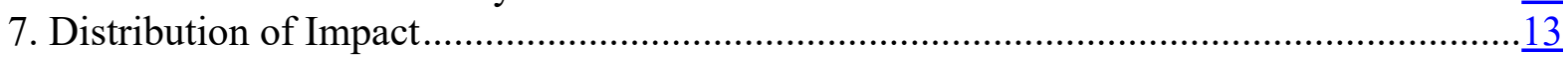

8. Current Account Response By Income Group............................................................ $\frac{13}{14}$

9. Saving and Investment Response By Income Group (Non-commodity EMs only) ............14

10. Recessions Associated with Credit Booms........................................................... 15

11. Recessions and High Public Debt Levels ............................................................... $\frac{16}{17}$

12. Pre-recession CA Deficits and Surpluses ............................................................ 
13. Share of Countries in Recession (in percent, GDP-weighted) ........................................19

14. Globally Synchronized Recessions..............................................................................

15. Number of Severe Epidemics and Natural Disasters ..................................................

16. CA and Trade Response to Severe Natural Disasters (75th), 1900-2018 ..........................21

17. CA and Trade Response to Severe Epidemics (75th), 1900-2018 ....................................22

18. CA and Trade Response to Severe Epidemics (75th), Major AEs and EMs .....................23

19. COVID-19 Impact on the Current Account for Economies in Recession ................................24

20. COVID-19 Impact on Saving for Economies in Recession .................................................

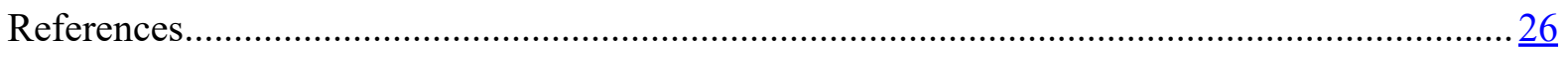

Annex Figures

1. Sectoral Response to Recessions ………………………………………………………. $\frac{32}{32}$

2. CA Sensitivity Over Time, 5 Year Response to Recessions, 5 year Window........................... $\frac{32}{32}$

3. Trade Response By Income Group (Non-commodity EMs only) ........................................... $\frac{32}{33}$

4. Recessions Associated with Banking Crises ........................................................................... $\frac{33}{33}$

5. Density of Public Debt to GDP By Income Group.................................................................

6. Recessions Associated with Sudden Stops ………………………………………………. $\frac{33}{34}$

7. Recessions and High Foreign Debt Liabilities .................................................................... $\frac{34}{34}$

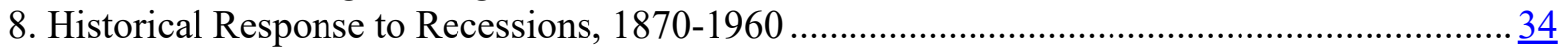

Annex Tables

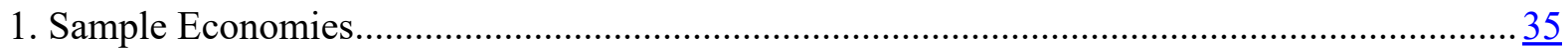

2. Current Account, Saving, and Investment in AEs and Non-commodity EMs ......................... $\frac{36}{36}$

3. The Role of Internal Imbalances, Additional Controls ........................................................... $\frac{36}{37}$

4. The Role of External Imbalances, Additional Controls .........................................................

5. Combining Internal and External Imbalances, Additional Controls........................................... $\frac{37}{38}$

6. Synchronization, and Internal and External Imbalances ……............................................... 


\section{INTRODUCTION}

Large economic downturns in the post WWII global economy were typically followed by narrowing global current account balances. Pre-crisis excesses were reined in and post-crisis deleveraging and sobering up meant less investment and more saving. Most prominent examples are the 1980s debt and oil crises or the Global Financial Crisis (GFC) where global imbalances, i.e. the sum of absolute surpluses and deficits, narrowed by around $1 \frac{1}{2}$ percent of global GDP and remained at this level for several years. The COVID-19 shock, however, left a very different imprint on external accounts: global imbalances increased by around $1 / 2$ percent of global GDP, implying that deficits and surpluses widened across economies. What is driving these different developments?

To better understand the underlying forces at work, this paper studies the dynamics of external accounts during economic recessions over the past 60 years and sheds light on key factors that shape these dynamics. Using Jorda's (2005) local projection method, we explore responses of current accounts (CA) and components for a horizon of up to 10 years. While following the vast literature on economic scarring, this paper focuses on one sector only - the external sector-and documents recession responses of its components across a broad set of countries, including emerging and developing economies, as well as various types of economic downturns, including crises triggered by natural disasters and epidemics.

Why looking at the CA balance and its components in the aftermath of economic downturns? The investment-saving balance usefully mirrors an economy's imbalances, and shocks typically dissipate by rebalancing investment and saving, as in the example of global crises above. Systematically documenting the external adjustment process to a broad set of recessions is the key contribution of this paper. In addition, much has been written recently about the impact of pandemics on output, interest rates, inequality, labor markets, CO2 emissions, and poverty (IMF 2021a, Emmerling et al. 2021, Jorda et al. 2020b), yet little on their effect on external accounts.

An extensive strand of literature on the impact of recessions provides strong evidence for large and persistent declines in output and substantial scarring (Cerra and Saxena 2008, Blanchard et al. 2015), ${ }^{2}$ typically accompanied by weakening consumption and investment. How large and long-lived is such recessionary effect for the external sector empirically? Building on this literature, we find that economic recessions trigger an increase in the current account of around $1 \frac{1}{2}$ percent of GDP within a year, maintained up to five years before gradually unwinding, driven by a sharp and persistent decline in investment. Aggregate saving drops temporarily, mainly driven by countercyclical fiscal policy, but turns positive over the medium to long term, fueled by (private) deleveraging. The impact is more persistent in advanced economies (AEs) than in emerging markets (EMs).

\footnotetext{
${ }^{2}$ See Cerra et al. 2020 for a literature review of the various channels through which recessions trigger long-run effects on potential.
} 
This paper is also closely related to work by Abiad et al. 2011 on trade dynamics following episodes of financial crises. Using a gravity framework, the authors find a sharp and persistent decline in a country's imports in the year following a banking and debt crisis, recovering to their gravity-predicted levels only after 10 years. Although this study covers data well after the GFC, a broader definition of recessions, and follows a different framework, the results are strinkingly similar, notably the strong decline and persistence in import volumes and the relative stability of exports.

The second part of this analysis, on what forces shape the CA response, is related to a strand of literature which focuses on CA adjustment episodes and external crises to analyze determinants which affect the crisis itself and/or post-crisis adjustment. Milesi-Feretti and Razin (1998) study sharp reductions in current account deficits in low- and middle-income countries and find their triggers in domestic factors, such as the low reserves, and external factors, such as unfavorable terms of trade. Lane and Milesi-Feretti (2012) analyze adjustments after the GFC in AEs and EMs and find that countries with excessive pre-crisis CA balances have experienced the largest contractions in their external balance, in line with results in this paper, and that adjustment in deficit countries was achieved primarily through demand compression rather than expenditure switching. Relatedly, Freund and Warnock (2007) examine episodes of CA adjustment in industrial countries and find that larger CA deficits take longer to adjust and are associated with significantly slower income growth. Other determinants of external crises, also used in the early warning literature, include the stock of foreign liabilities and its currency denomination (see, for instance, Cubeddu et al. 2021).

Looking at recessions in general (i.e. not specifically external crises or certain adjustment episodes) allows us compare external sector outcomes and CA adjustment paths during various types of downturns, in surplus and deficit countries, and in the presence of several forms of vulnerabilities, and thus to provide a systematic overview on the behavior of external accounts during recessions since the 1960ies. Based on 278 recession episodes, we find that the strengthening of the CA is significantly more pronounced when internal and external imbalances are present before the downturn, i.e. when pre-recession private or public borrowing is elevated, or when sustained CA deficits or higher external debt levels exist prior to the downturn. Investment, for instance, falls by 4 percent during recessions associated with credit booms, against 2 percent in recession without such boom. Countries with larger buffers (e.g. CA surplus economies or countries with lower public debt) were able to use them and dissave during recessions, thereby attenuating the fall in investment. Internal imbalances push up the CA balance in particular in the medium to longer term, while external imbalances affect the CA path more immediately. We also find that the CA increases by less when recessions are more synchronized across countries as exports fall in tandem with imports due to faltering global demand. During severe natural disasters or epidemics, CAs tend to weaken in the short term. These findings are robust against the inclusion of various additional controls, and alternative definitions of recessions and vulnerabilities. 
Consistent with these findings, the COVID shock with its comparatively moderate pre-existing imbalances yet high synchronization, had a muted effect on global CA balances. At the onset of the GFC, for example, private credit expansion and housing booms and/or excessive public borrowing inflated domestic balance sheets, and many economies had been running substantial CA deficits for years. The subsequent deleveraging implied a sustained narrowing in CA deficits. The COVID-19 shock, however, was not accompanied by such financial sector turmoil and excessive private or public sector borrowing in CA deficit economies. The 2020 compositional changes, however, were unique: exceptional private saving offset historical public dissaving while investment fell only mildly.

The rest of the paper is organized as follows. Section II describes data and methodology; section III discusses empirical results of recessions on external variables; section IV analyzes vulnerabilities and conditions affecting the path of external accounts after recessions; section V compares these results with the impact of the COVID-19 shock; and section VI concludes.

\section{Data ANd Methodology}

The paper uses yearly, unbalanced panel data over a period of 1960 to 2019 to study past recessions, purposely excluding the COVID-related downturn which is analyzed separately. The baseline sample covers 49 advanced and emerging economies which represent around 90 percent of global GDP. To better understand differences among income group and commodity exporting economies, we present a separate set of results based on samples of 35 advanced and 43 emerging markets, further differentiated by whether the country is a main commodity exporter or not (Annex Table 1).

Figure 1: Number of Countries in Recession, 1960-2019

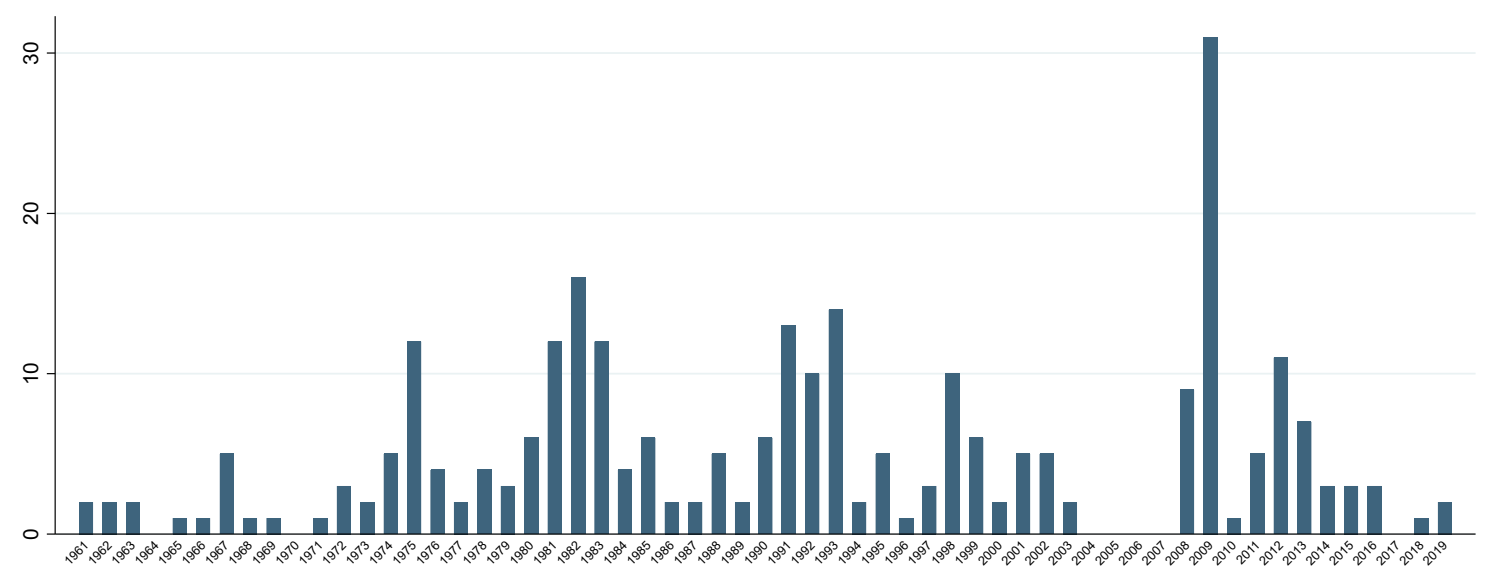

Notes: Baseline sample of 49 advanced and emerging markets.

Macroeconomic variables are taken from the IMF World Economic Outlook and International Financial Statistics databases, and the OECD national account statistics (see detailed data sources in Annex 1). To study the impact of epidemics and natural disasters on 
the current account, we augment the historical dataset by Jorda et al. 2017, covering the time span from 1870 to 2016 for 17 countries (unbalanced), with data on natural disasters from the EM-DAT database and on epidemics from Li and Coppo 2020, covering the years from 1900 until 2018.

To optimize the number of observations on economic recession events across a broad set of countries, we employ a simple and widely applicable definition and denote a recession year as a year with negative real GDP growth. Starting in 1960, for our baseline sample, we obtain an average of almost 5 recession events per year (Figure 1). In total, the baseline sample includes 278 recession events up to 2019. ${ }^{3,4}$ The extended samples by income groups comprise 180 recession episodes for AEs, 114 for non-commodity exporting EMs, and 212 for commodity-exporting EMs (Figure 2).

Figure 2: Number of Countries in Recession by Income Group, 1960-2019

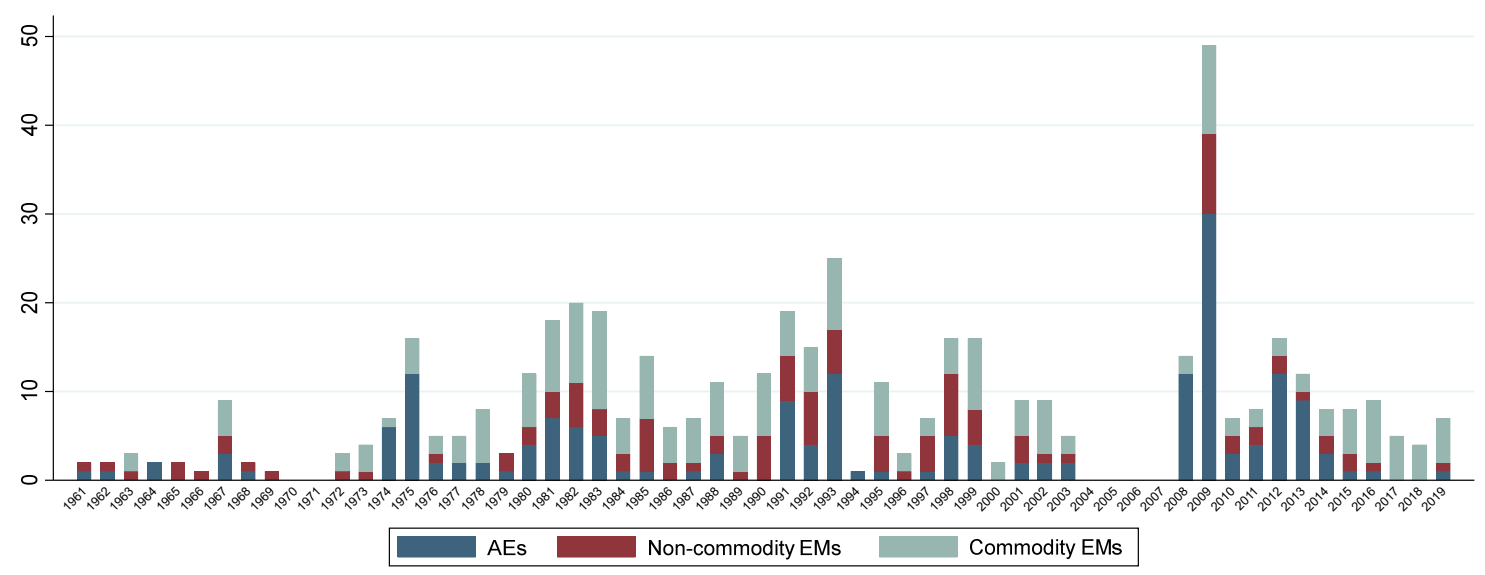

Notes: Extended sample of 35 advanced economies (AEs), 22 non-commodity exporting emerging markets (EMs), and 21 commodityexporting emerging markets.

The definition of recession includes prolonged recessions with negative growth for more than a year. To address a possible distortion from repeated or prolonged recessions, we include two lags of the recession variable and employ robustness checks using only singleyear recessions, which yield similar results. While we don't differentiate between the severity of economic downturns in the recession indicator variable itself, we indirectly account for this factor by analyzing the role of various imbalances (and types of economic crises) which are known to be associated with longer and more severe recessions.

To estimate the cumulative response of external sector variables in country $i$ to an economic recession in year $t$, the paper follows Jorda's (2005) local projection methodology, estimated with Driscoll Kraay standard errors to correct for serial correlation and heteroskedasticity. Let $\boldsymbol{Y}^{\prime}{ }_{i, t}$ denote the vector of changes in external sector variables relative to base year t-1, including current account balance, investment and saving as a share of GDP

\footnotetext{
${ }^{3}$ Compared with a total of 47 in 2020 alone.

${ }^{4}$ The number of recession episodes is somewhat lower when including certain country-specific factors in the estimation whose data series are shorter, such as credit booms or banking crises, for instance.
} 
as well as export and imports volumes and exchange rates. The coefficient of interest is $\beta^{h}$, notably its path during the years $\mathrm{h} \geq 0$ following recession $R_{i, t}$.

We estimate the following equation:

$$
\boldsymbol{Y}_{i, t+h}^{\prime}=\alpha_{i}^{h}+\gamma_{t}^{h}+\beta^{h} R_{i, t}+\sum_{k=1}^{2}\left(\beta_{k}^{h} R_{i, t-k}+\vartheta_{k}^{h} \boldsymbol{Y}_{i, t-k}^{\prime}\right)+e_{i, t}^{h}
$$

Where $\alpha_{i}^{h}$ and $\gamma_{t}^{h}$ are country and time fixed effects and $e_{i, t}^{h}$ the error term. Two lags of the dependent variable and recession dummy are included. As the horizon of interest is relatively long due to the impact's remarkable persistence, and given the efficiency loss that the local projections method suffers at increasing horizon $h$, we address possible efficiency concerns by including the residual from the estimation for horizon $h-1$ as an additional regressor in the estimation for horizon $h$. Including the residual also addresses a potential bias identified in Teulings and Zubanov (2014), ${ }^{5}$ as innovations from in-between horizons are included in the error terms of the preceding horizon $h-1$. Historic, pre-1960 recessions, natural disasters, and epidemics, as well as regressions with the emerging markets subsample are estimated using Cook's distance correction.

To analyze how country-specific vulnerabilities or certain types of recessions affect the dynamics of external variables during recessions, we estimate the response of $\boldsymbol{Y}_{i, t}{ }_{i, t}$ to recession $R_{i, t}$ when pre-existing vulnerability $V_{u} l_{i, t}$ is present and compare this response to recessions when such vulnerability is not present. We test this by interacting the recession variable with the vulnerability dummy $R_{i, t} * V u l n_{i, t}$. The proximity of the vulnerability's occurrence and the recession itself or the time horizon of the conditioning variable varies across variables. Recessions associated with credit booms, for instance, are defined as such if the credit boom's peak occurs up to 3 years prior to a recession; sustained CA deficits are defined as negative CA deficits (average) over 5 years prior to a recession.

We focus on the most parsimonious specification as in (1) and provide tables with additional controls, including openness, exchange rate movements, and relative growth, as well as multiple vulnerabilities, to complement the analysis. Estimating external sector variables in changes (or growth rates) eliminates the need to include many of the usual determinants of current accounts (Cubeddu et al. 2018) and helps address the strong autocorrelation that current account data typically display. We also control for country specific time-invariant factors as well as global trends which might further affect changes in the CA balance.

\footnotetext{
${ }^{5}$ Teulings and Zubanov (2014) show that not controlling for innovations in the regressors between periods $t$ and $t+h$ when estimating the response at horizon $h$ can bias the local projection estimates in particular at longer horizons. Additional robustness checks following the Teulings and Zubanov (2014) suggestion yield very similar results to including the residual from the preceding horizon h-1.
} 


\section{HOW DO CURRENT ACCOUNT BALANCES BEHAVE DURING RECESSIONS?}

Recessions trigger an average improvement in the CA balance of around $1 \frac{1}{2}$ percent of GDP for up to five years after the recession (Figure 3), estimated using specification (1). The path of the current account is highly persistent even beyond the medium term and returns to pre-crises levels only after around 10 years. ${ }^{6}$

Figure 3: Current Account Response to Recessions

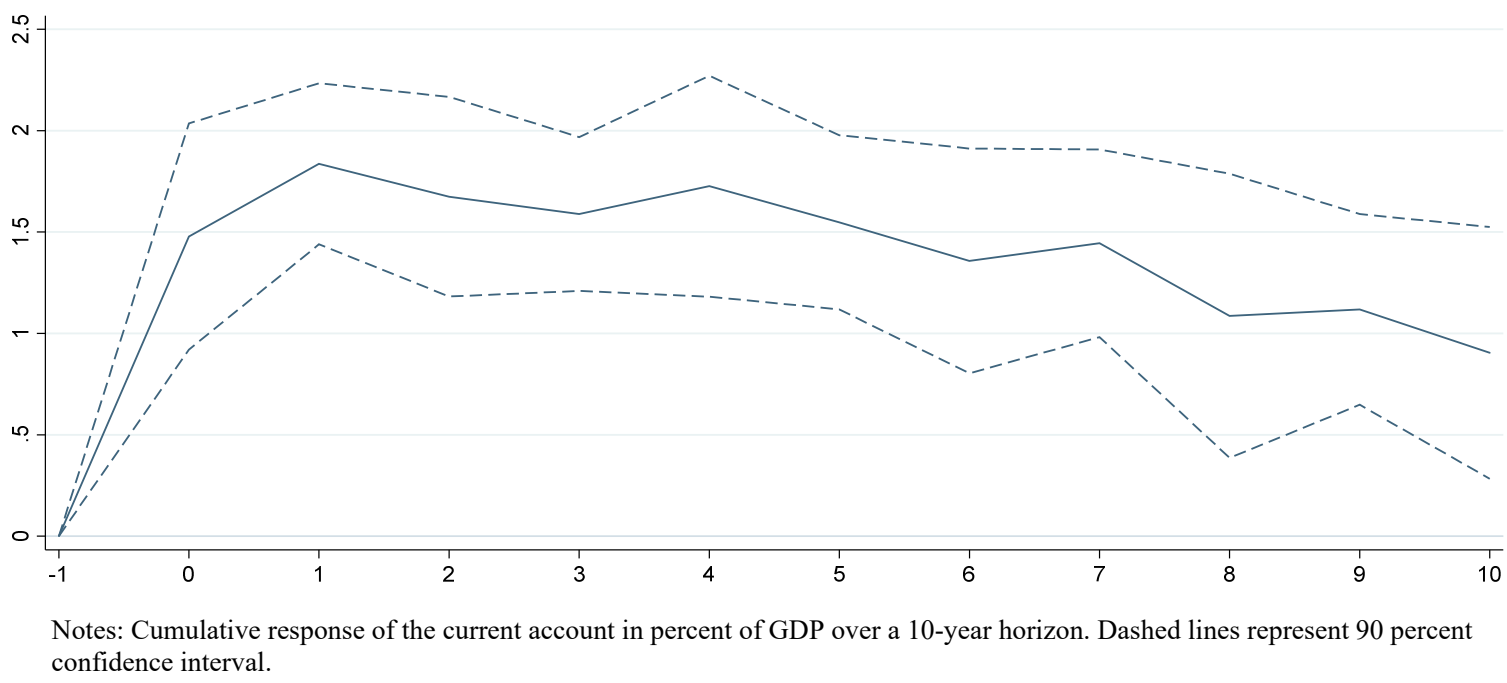

When decomposing the CA into the saving and investment balance,

$$
C A=\text { Saving }{ }^{\text {Public }}+\text { Saving Private }- \text { Investment }
$$

and regressing the individual components following specification (1), we find that the CA response is driven by a sharp and persistent decline in investment of around $2 \frac{1}{2}$ percent of GDP in the year following the recession (Figure 4). The CA improves as the response of aggregate saving (private and public), falling by 1 percent, fails to offset the decline in investment. Countercyclical fiscal policy during recessions leads to public dissaving of almost 2 percent of GDP in the post-recession year, while private saving increases, mainly driven by household sector deleveraging. ${ }^{7}$ The response of saving is short-lived, around 3 years, driven by the quick return of public saving to and beyond pre-crisis levels, to rebuild buffers and/or accommodate financing constraints.

\footnotetext{
${ }^{6}$ Alternative definitions of recession (e.g. using the first year of negative growth only) yield very similar results. ${ }^{7}$ Decomposing private saving in household and non-financial corporate sectors for a subsample of 20 countries (due to data availability) we find that the positive saving response by private saving is mainly explained by the household sector as saving by non-financial corporates declines somewhat (at weak significance) as companies tend to live off their savings or increase their leverage (Annex Figure 1). These findings differ from Allen 2019 who shows that the non-financial corporate (and government) sector was driving external adjustment in the GFC aftermath in advanced economies.
} 
Figure 4: Saving and Investment Response to Recessions
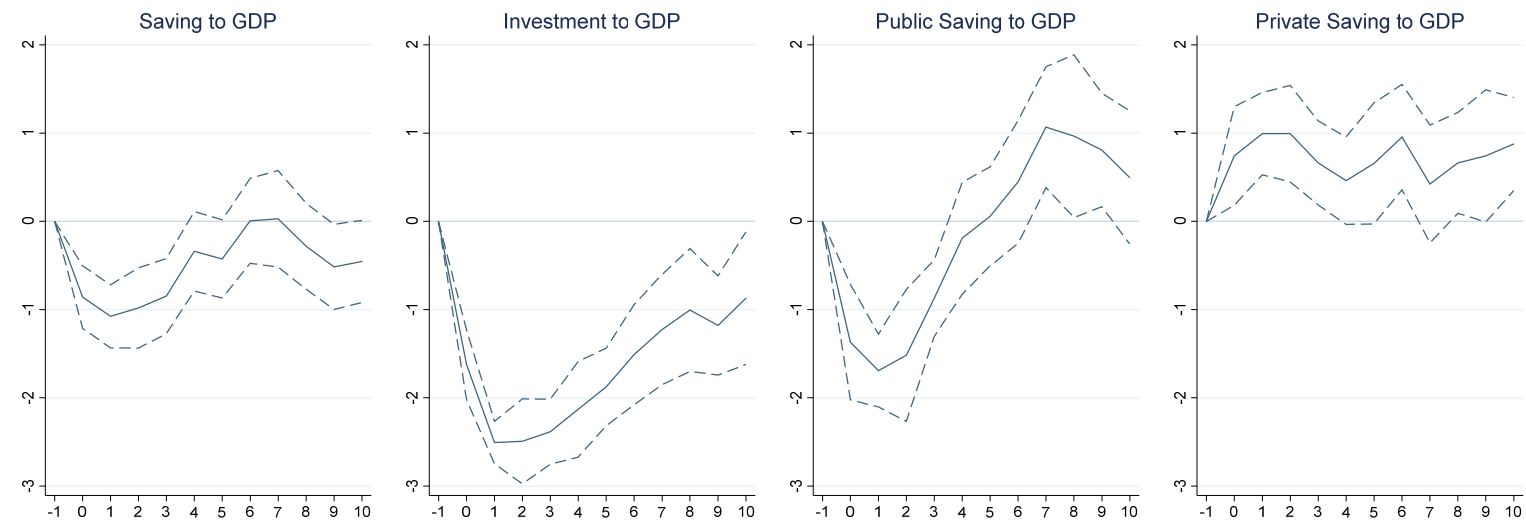

Notes: Cumulative response of the investment and saving in percent of GDP over a 10-year horizon. Dashed lines represent 90 percent confidence interval.

Figure 5 depicts the response to recessions from a trade angle. Imports, falling around 13 percent year on year (in volumes), mirror the collapse in investment and private deleveraging. Exports, in turn, are only mildly affected, declining by around 3 percent. Despite using a more recent and thus longer sample in this paper, these results are close to the findings of Abiad et al. 2011 who estimate a decline of around 19 percent for imports and 4 percent for exports in a gravity model framework with data up to 2009. Our estimations show that import volumes are suppressed, on average, for more than 10 years ${ }^{8}$ while exports recover over the medium term. Exchange rates depreciate as expected, with the NEER falling roughly 40 percent and the REER 10 percent. The exchange rate developments are mainly driven by the emerging markets in the sample.

Figure 5: Trade and Exchange Rates Response to Recessions
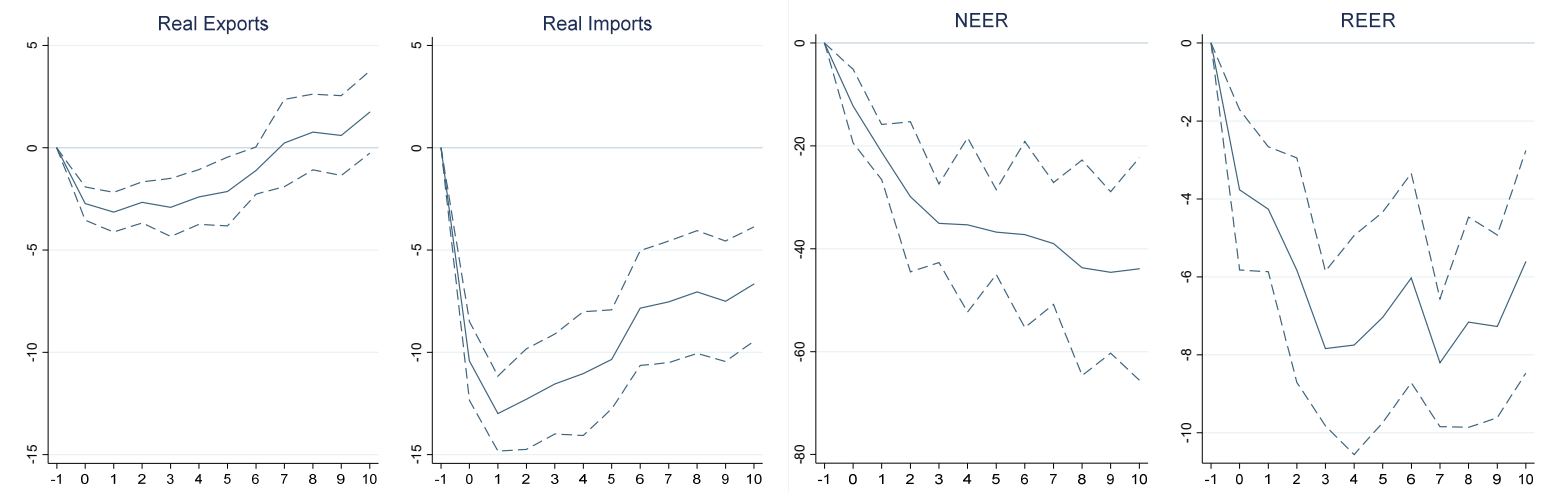

Notes: Export and imports in volumes. Cumulative response in percent over a 10-year horizon. Dashed lines represent 90 percent confidence interval.

${ }^{8}$ Differentiating by goods categories (for a subset of countries and over a shorter horizon given data restrictions), we find that intermediate goods imports for manufacturing show less severe and less persistent impact than total imports. 


\section{Current Account Sensitivity to Recessions over Time}

Since the 1960s, various forms of economic downturns have rattled economies, from supply to demand shocks; from end-of-cycle to policy-induced slowdowns. To understand whether there have been variations in the response of the CA to recessions, we estimate 5year rolling windows of the $\mathrm{CA}$ response one year after the recession.

Figure 6: Current Account Sensitivity to Recessions over Time

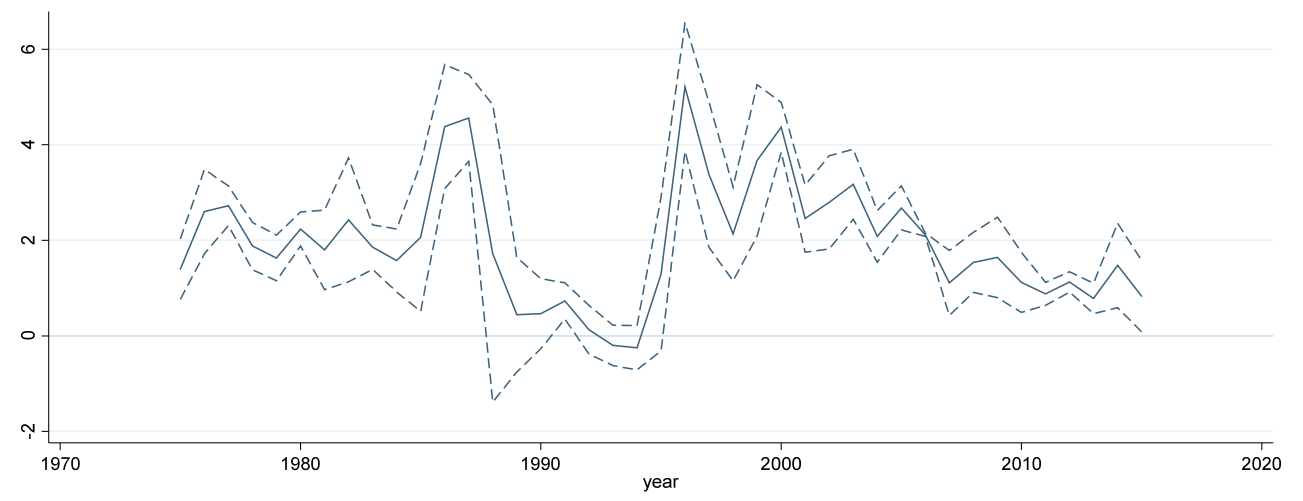

Notes: CA in percent of GDP. 5-year rolling estimations of the cumulative CA response one year after the recession. Dashed lines represent 90 percent confidence interval. Time fixed effects omitted.

Figure 6 shows that the impact of downturns on the CA balance has been oscillating around 2 percent with the exception of the late 1980ies to mid-1990ies, when the CA response first spiked to around 4 percent, then dropped so insignificant levels and resurfaced in the mid-1990ies. Since then, the CA response has trended downward to reach around 1 percent of GDP in the past decade, including during the GFC. The lowest CA sensitivities coincided with the cluster of - relatively synchronized-economic recessions around the European Exchange Rate Mechanism crisis, and later with the GFC, as analyzed in more detail below. A similar exercise using the medium term impact $(t+5)$ instead of the short term impact $(\mathrm{t}+1)$ shows that persistence seems to have increased in the aftermath of the GFC (Annex Figure 2).

\section{Distribution of Impact}

To test whether the CA response is driven by extreme adjustments in certain countries, or whether specific CA components are "at risk" during economic downturns, ${ }^{9}$ we estimate equation (1) with quantile regressions and derive the impact of recessions on external variables at the $10^{\text {th }}, 50^{\text {th }}$ and $90^{\text {th }}$ percentile (Figure 7 ). The CA response is surprisingly evenly distributed with low-CA adjuster countries and high-CA adjuster countries moving in a similar pattern. The similarities are most striking for investment, where dispersion is very small. The only variable in which countries diverge in their responses is private saving. The lowest decile experiences very little accumulation of saving, if not

\footnotetext{
${ }^{9}$ See Adrian et al 2018 and 2019 for analyses on "growth at risk", and Jorda et al 2020a for the impact of business credit booms on macroeconomic variables.
} 
dissaving, while the highest decile leads the deleveraging process. We will revisit this observation in Section IV when looking at the role of imbalances.

Figure 7: Distribution of Impact
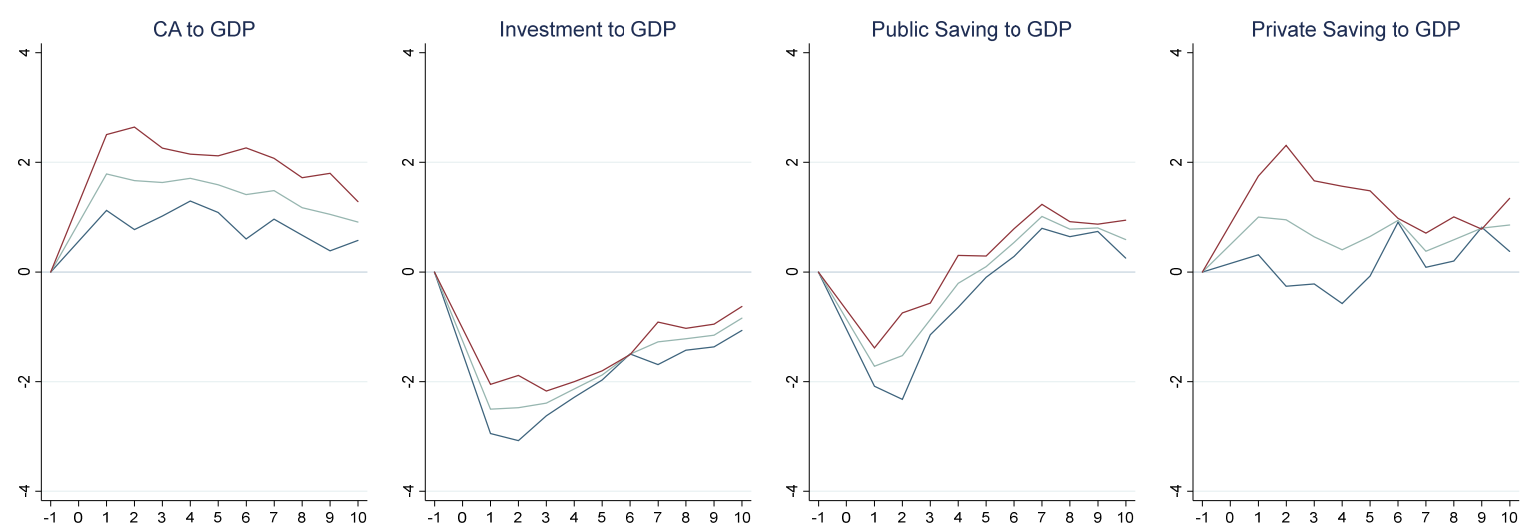

Notes: Impact of recessions on the 10th (blue), 50th, and 90th (red) percentile of the CA and its components.

\section{Income Groups and Commodity Exporters}

Looking separately at advanced and emerging markets of the expanded sample, and differentiating between commodity and non-commodity exporters, we find that CA increases in non-commodity EMs are significantly less persistent than in AEs (Figure 8, see also Annex Table 2): CA balances return to pre-crisis levels in around 5 years in EMs, while AEs' CAs increase remains above pre-recession level, even at a 10 year horizon. No significant CA improvement can be found in the group of commodity exporters.

Figure 8: Current Account Response By Income Group
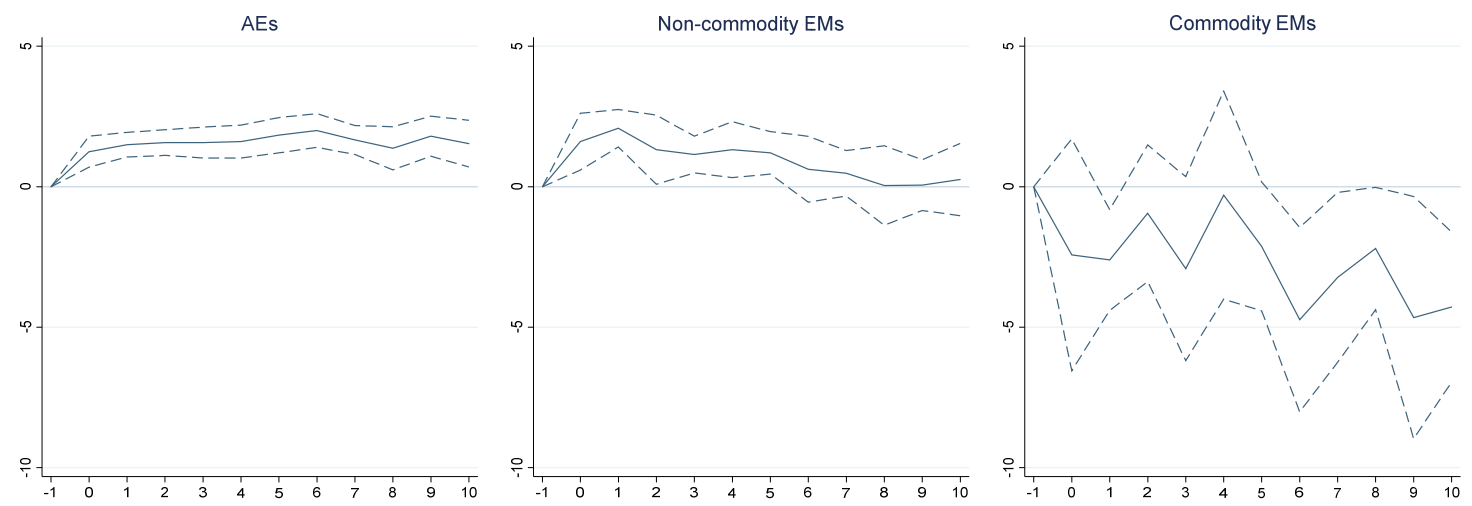

Notes: Cumulative response of the CA balance in percent of GDP. Dashed lines represent 90 percent confidence interval.

The differences between AEs and non-commodity EMs are driven by the saving response (Figure 9). Private saving in AEs increases by around one percent and remains elevated while returning to precrisis levels within two years in EMs. Although public dissaving in AEs is stronger, mainly reflecting larger fiscal space, the cumulative (positive) change in aggregate saving is significantly higher at longer horizons in AEs (see also Annex 
Table 2). Additional control variables, such as openness and exchange rate movement in the recession year do not affect this pattern. Controlling for relative growth lowers the short-term impact somewhat, while increasing the medium to longer term impact for AEs and EMs.

Figure 9: Saving and Investment Response By Income Group (Non-commodity EMs only)


Notes: Cumulative response of investment and saving in percent of GDP over a 10-year horizon by country group. Dashed lines represent 90 percent confidence interval. Private and public saving series start in the early to late 1990ies for most EMs while total saving data are available from the late 1960ies onwards.

Exports and imports have a widely different post-recession trajectory in AMs and non-commodity EMs (Annex Figure 3). Driven by significantly stronger depreciation, imports fall by around 17 percent in EMs but only 6 percent in AEs in the first year after the recession. Exports are mildly affected in AEs, and display a relatively high dispersion in EMs, falling around 10 percent.

\section{WHAT FACTORS SHAPE THE CA RESPONSE?}

The following sections discuss how various vulnerabilities and crisis conditions influence the response of external variables, using the baseline sample for optimal data coverage.

\section{A. Internal Imbalances}

Internal imbalances, as reflected in excessive private and public borrowing, are linked to stronger and more persistent $\mathrm{CA}$ adjustments after recessions. In following analysis, internal imbalances are proxied by credit booms, banking crises and public debt levels.

\section{Credit Booms: CA Adjustment Through Falling Investment and Private Deleveraging}

Recessions associated with credit booms ${ }^{10}$ trigger a contemporaneous increase in the CA balance of around 2 percent of GDP which rises to 3 percent over the estimation horizon. Recessions without prior excessive borrowing, on the contrary, see their CA balance

\footnotetext{
${ }^{10}$ Credit boom episodes are taken from Dell'Ariccia et al. 2020, see annex on data sources for definition. Recessions associated with credit booms are defined as recessions which occur up to 3 years after the end of a credit boom. 48 such recessions are identified for our baseline sample.
} 
gradually return to pre-crisis levels (Figure 10). The diverging impact is driven by a stronger investment response, falling by 4 percent in credit boom economies, and stronger private deleveraging - reining in past excesses. Short term countercyclical fiscal policy has proven more expansive among credit boom economies and public dissaving more than offsets private saving. Consequently, credit boomers see their aggregate saving decline by more in the short and medium term than non-boomers but gradually return thereafter, feeding the increasing gap in CA responses over time (see also Table 1). The sustained decline in investment, which drives the persistent $\mathrm{CA}$ improvement, is consistent with the literature on credit booms which shows that recessions associated with credit booms tend to be stronger and leave deeper scars in the macroeconomy (see Dell'Ariccia et al. 2020 and Jorda et al. 2020a for household borrowing in particular).

Figure 10: Recessions Associated with Credit Booms
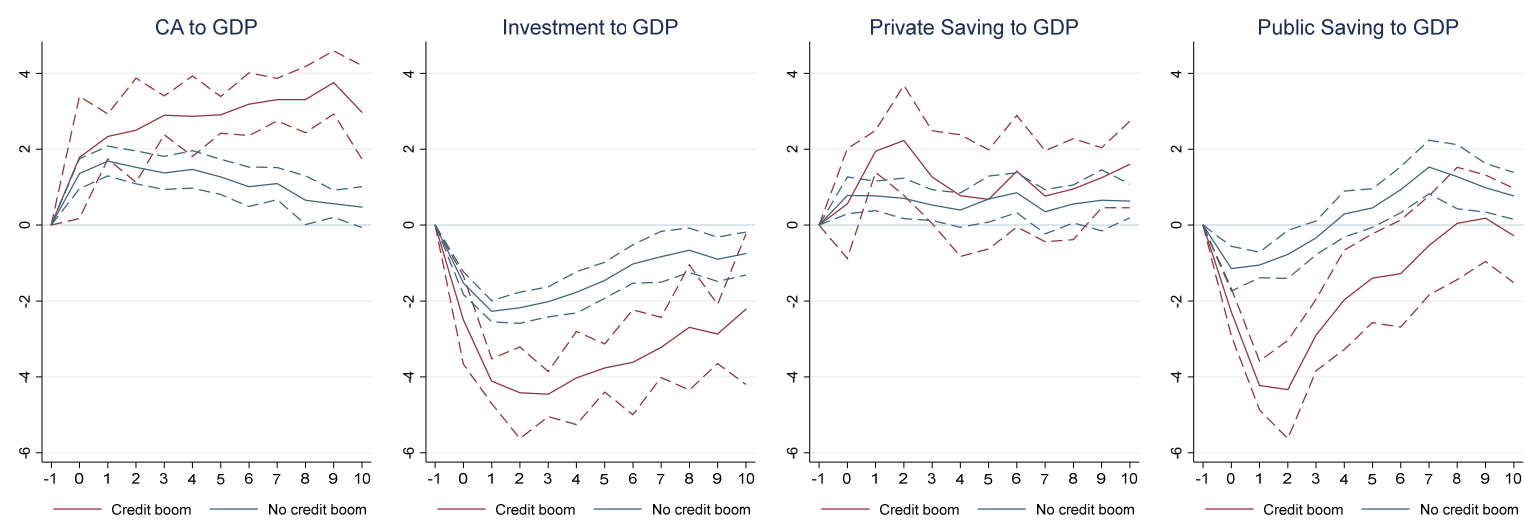

Notes: Cumulative response of CA balances and components in percent of GDP over a 10-year horizon. Dashed lines represent 90 percent confidence interval. Credit booms are taken from Dell'Arriccia et al. 2020. Recessions associated with credit booms are defined as recessions which occur up to 3 years after the end of a credit boom.

A similar picture arises from banking crises (Annex Figure 4) but with a more pronounced role of private deleveraging, possibly due to financial conditions tightening quickly in banking crises, while credit boom peaks might not always be accompanied by such rapid tightening. The underlying data series on credit booms and banking crises are very similar with two exceptions: banking crises in the 1990s were less often accompanied by credit booms while more countries faced a credit boom than a banking crisis during the GFC.

\section{High Public Debt: CA Adjustment Reflects Rebuilding Fiscal Buffers in the Medium Term}

Higher public debt levels ${ }^{11}$ prior to recessions are associated with stronger CA increases in the medium term. Given smaller buffers or little fiscal space, high-debt economies lack a

11 The dummy variable High public debt assumes the value one if the 3-year average of a countries' public debt to GDP ratio prior to the recession year is above the $75^{\text {th }}$ percentile of the same horizon, by income group (see Annex Figure 5 for the sample's density of public debt by income group, noting the unbalanced time horizon for AEs and EMs). Conducting the analysis with a threshold of the median yields broadly similar results, but somewhat lower significance. 
significant countercyclical fiscal policy response in the short run (Figure 11). They further experience rising public saving in the medium term, as financing constraints becoming binding. Although recessions in low-public debt economies trigger somewhat more private deleveraging in the short term, the aggregate saving response is significantly stronger in high-public debt economies throughout the considered horizon (see also Table 1).

Figure 11: Recessions and High Public Debt Levels
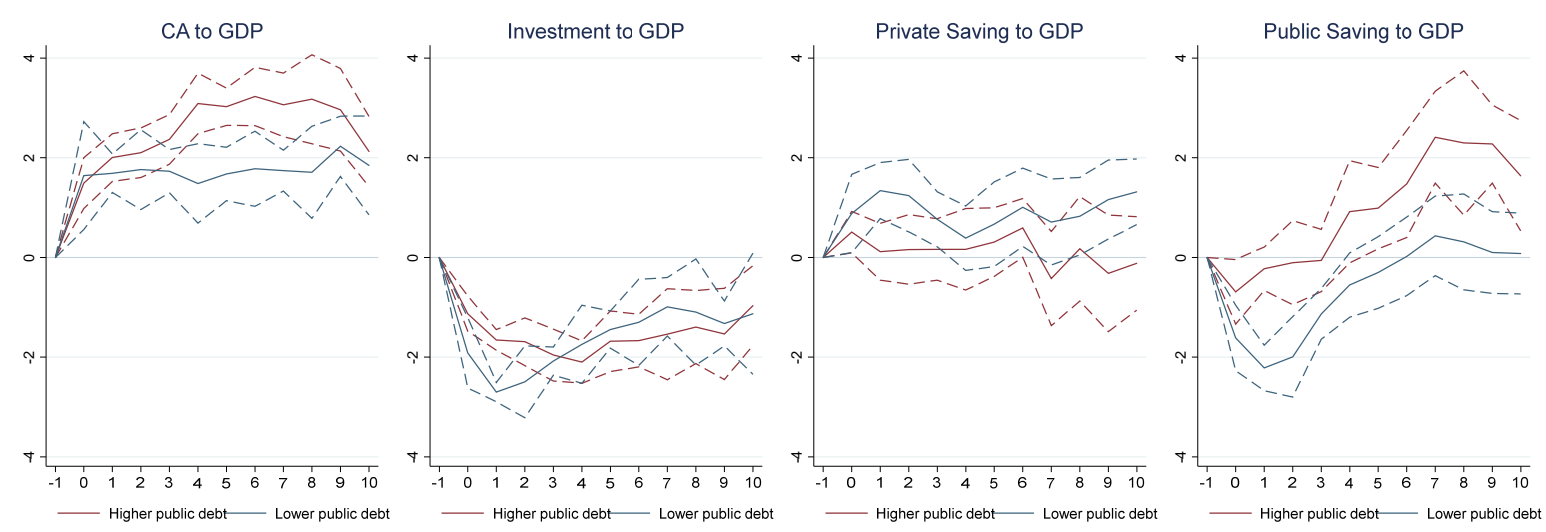

Notes: Cumulative response of CA balances and components in percent of GDP over a 10-year horizon. Dashed lines represent 90 percent confidence interval. Higher public debt is defined as debt above the 75th percentile, lower public debt as debt below the 75th percentile within income group (AEs and EMs).

Table 1: Current Account and Saving-Investment Balances with Internal Imbalances

\begin{tabular}{|c|c|c|c|c|c|c|c|c|c|}
\hline \multirow[b]{3}{*}{ VARIABLES } & (1) & (2) & (3) & (4) & (5) & (6) & (7) & (8) & (9) \\
\hline & \multicolumn{3}{|c|}{ CA } & \multicolumn{3}{|c|}{ Saving } & \multicolumn{3}{|c|}{ Investment } \\
\hline & 1 year & 5 years & 9 years & 1 year & 5 years & 9 years & 1 year & 5 years & 9 years \\
\hline \multirow[t]{2}{*}{ Recession } & $1.709 * * *$ & $1.266 * * *$ & $1.126^{* * *}$ & $-0.656 * * *$ & $0.711^{* *}$ & 0.367 & $-2.330 * * *$ & $-0.805^{* * *}$ & $-0.688^{* *}$ \\
\hline & $(0.236)$ & $(0.331)$ & $(0.254)$ & $(0.208)$ & $(0.348)$ & $(0.323)$ & $(0.130)$ & $(0.283)$ & $(0.281)$ \\
\hline \multirow[t]{2}{*}{ Recession*credit boom } & $1.401 * * *$ & $3.061^{* * *}$ & $4.743^{* * *}$ & $-2.131 * * *$ & $-2.070^{* * *}$ & 0.962 & $-2.682^{* * *}$ & $-4.245^{* * *}$ & $-3.224 * * *$ \\
\hline & $(0.461)$ & $(0.360)$ & $(0.514)$ & $(0.382)$ & $(0.709)$ & $(0.634)$ & $(0.494)$ & $(0.444)$ & $(0.405)$ \\
\hline \multirow{2}{*}{ Recession*high debt } & -0.042 & $1.567^{* * *}$ & $0.967^{*}$ & $0.944^{* * *}$ & $1.026 * * *$ & $1.558^{* * *}$ & $1.131^{* * *}$ & -0.378 & 0.119 \\
\hline & $(0.313)$ & $(0.368)$ & $(0.506)$ & $(0.252)$ & $(0.323)$ & $(0.565)$ & $(0.164)$ & $(0.235)$ & $(0.398)$ \\
\hline \multirow[t]{2}{*}{ Constant } & $-0.867 * * *$ & $-1.584^{* * *}$ & $-0.407^{*}$ & $-0.413 * * *$ & $-0.881^{* * *}$ & $-0.614^{* * *}$ & $0.463^{* * *}$ & $0.470^{* * *}$ & $0.565^{* * *}$ \\
\hline & $(0.143)$ & $(0.247)$ & $(0.221)$ & $(0.121)$ & $(0.190)$ & $(0.167)$ & $(0.082)$ & $(0.157)$ & $(0.163)$ \\
\hline Observations & 1,482 & 1,385 & 1,195 & 1,456 & 1,359 & 1,165 & 1,455 & 1,358 & 1,164 \\
\hline Number of groups & 49 & 48 & 48 & 49 & 49 & 49 & 49 & 49 & 49 \\
\hline Within R-squared & 0.537 & 0.541 & 0.584 & 0.572 & 0.586 & 0.577 & 0.668 & 0.603 & 0.604 \\
\hline
\end{tabular}

To understand whether the coefficients on high credit growth and high public debt are picking up similar aspects of excessive leverage, we include both imbalances in the estimation. The above described effects are highly robust to this inclusion, with credit booms paralyzing investment, and high public debt pushing up saving, notably in the medium term (Table 1). Additional controls, notably relative growth, lower the short-term effects, but don't 
change the results qualitatively on how imbalances affect the response of external accounts to recessions (Annex Table 3).

\section{B. External Imbalances}

External vulnerabilities significantly shape recessionary external adjustment, mainly through stronger saving responses, notably when external financing constraints are prevalent.

\section{Sustained CA Deficits: CA Adjustment Through Private and Public Deleveraging}

Economies with pre-recession CA deficits ${ }^{12}$ typically experience CA increases of around 2 percent of GDP, while pre-recession CA surpluses remain relatively stable as surplus economies live off their buffers dampening the recession-induced fall in investment (Figure 12). ${ }^{13}$ Similar to credit booms, the CA adjustment reflects a striking difference in the private saving responses: private saving increases strongly in CA deficit economies (mirrored by a steeper fall in investment in the short term) while private saving remains constant during recessions in surplus economies (relative to GDP). Controlling for relative growth vis-à-vis trade partners to address possible omitted variable concerns, as deficit economies might experience relatively worse recessions, does not affect the results qualitatively (Annex Table 4). The asymmetric responses between deficit and surplus economies explain why recessions are typically accompanied by a narrowing of global CA imbalances, as observed in the GFC and other severe downturns and as further detailed below.

Figure 12: Pre-Recession CA Deficits and Surpluses


Notes: Cumulative response of CA balances and components in percent of GDP over a 10-year horizon. Dashed lines represent 90 percent confidence interval. Prior deficit (surplus) is defined as running a CA deficit (surplus), on average, over 5 years preceding the recession.

\footnotetext{
${ }^{12}$ Prior deficit (surplus) is defined as running a CA deficit (surplus), on average, over 5 years preceding the recession.

${ }^{13}$ See Allen 2019 for a similar finding on CA adjustment during the GFC.
} 
Using sudden stops ${ }^{14}$ in capital flows instead of CA deficits ${ }^{15}$, to better capture financing constraints associated with the downturn, amplifies the impact on the current account somewhat (to around 3 percent of GDP) and displays similar response paths as the deficit-surplus estimates (Annex Figure 6). The same exercise for higher/lower stocks of external debt liabilities ${ }^{16}$ yields comparable results, with a somewhat more pronounced role of public saving (Annex Figure 7). High foreign currency exposure ${ }^{17}$, however, captured by the share of foreign currency-denominated debt liabilities and typically an important determinant for external crises (see for instance Cubeddu et al. 2021), is not associated with a larger increase in the CA balance. Rather the opposite, estimations suggest that investment seems to return somewhat faster in high FX liability economies, as tapping the (international) markets might be easier for countries which had a larger and established exposure before the downturn.

\section{Summarizing Imbalances}

Table 2: Combining Internal and External Imbalances

\begin{tabular}{|c|c|c|c|c|c|c|c|c|c|}
\hline \multirow[b]{3}{*}{ VARIABLES } & $(1)$ & $(2)$ & (3) & (4) & $(5)$ & $(6)$ & (7) & (8) & (9) \\
\hline & \multicolumn{3}{|c|}{ CA } & \multicolumn{3}{|c|}{ Saving } & \multicolumn{3}{|c|}{ Investment } \\
\hline & 1 year & 5 years & 9 years & 1 year & 5 years & 9 years & 1 year & 5 years & 9 years \\
\hline Recession & $\begin{array}{l}-0.172 \\
(0.328)\end{array}$ & $\begin{array}{c}-1.178^{* * *} \\
(0.316)\end{array}$ & $\begin{array}{c}-0.977^{* * *} \\
(0.297)\end{array}$ & $\begin{array}{c}-1.734^{* * *} \\
(0.360)\end{array}$ & $\begin{array}{c}-1.407^{* * *} \\
(0.213)\end{array}$ & $\begin{array}{c}-1.149 * * * \\
(0.310)\end{array}$ & $\begin{array}{c}-1.397 * * * \\
(0.222)\end{array}$ & $\begin{array}{l}-0.251 \\
(0.355)\end{array}$ & $\begin{array}{c}0.120 \\
(0.339)\end{array}$ \\
\hline Recession*credit boom & $\begin{array}{c}0.129 \\
(0.514)\end{array}$ & $\begin{array}{c}1.166^{* * *} \\
(0.415)\end{array}$ & $\begin{array}{c}2.895^{* * *} \\
(0.522)\end{array}$ & $\begin{array}{c}-2.754^{* * *} \\
(0.433)\end{array}$ & $\begin{array}{c}-3.389 * * * \\
(0.766)\end{array}$ & $\begin{array}{l}-0.112 \\
(0.517)\end{array}$ & $\begin{array}{c}-2.166^{* * *} \\
(0.529)\end{array}$ & $\begin{array}{c}-3.542^{* * *} \\
(0.528)\end{array}$ & $\begin{array}{c}-2.578^{* * *} \\
(0.392)\end{array}$ \\
\hline Recession*high debt & $\begin{array}{l}-0.367 \\
(0.294)\end{array}$ & $\begin{array}{c}1.208 * * * \\
(0.352)\end{array}$ & $\begin{array}{c}0.788 \\
(0.502)\end{array}$ & $\begin{array}{c}0.785^{* * *} \\
(0.221)\end{array}$ & $\begin{array}{c}0.646 * * \\
(0.311)\end{array}$ & $\begin{array}{c}1.456 * * * \\
(0.505)\end{array}$ & $\begin{array}{c}1.199 * * * \\
(0.164)\end{array}$ & $\begin{array}{l}-0.165 \\
(0.240)\end{array}$ & $\begin{array}{c}0.170 \\
(0.465)\end{array}$ \\
\hline Recession*CA deficit & $\begin{array}{c}1.859 * * * \\
(0.381)\end{array}$ & $\begin{array}{c}2.322^{* * *} \\
(0.344)\end{array}$ & $\begin{array}{c}1.752^{* * *} \\
(0.464)\end{array}$ & $\begin{array}{c}1.245^{* * *} \\
(0.363)\end{array}$ & $\begin{array}{c}2.268^{* * *} \\
(0.339)\end{array}$ & $\begin{array}{c}1.616^{* * *} \\
(0.325)\end{array}$ & $\begin{array}{c}-0.873 * * * \\
(0.259)\end{array}$ & $\begin{array}{l}-0.482 \\
(0.517)\end{array}$ & $\begin{array}{l}-0.595 \\
(0.572)\end{array}$ \\
\hline Recession*high external debt & $\begin{array}{c}1.085^{* * *} \\
(0.268)\end{array}$ & $\begin{array}{c}1.262^{* * *} \\
(0.454)\end{array}$ & $\begin{array}{c}1.269 * * * \\
(0.376)\end{array}$ & $\begin{array}{c}0.669 * * \\
(0.293)\end{array}$ & $\begin{array}{c}1.216^{* * *} \\
(0.361)\end{array}$ & $\begin{array}{c}0.509 \\
(0.610)\end{array}$ & $\begin{array}{c}-0.351 * * \\
(0.173)\end{array}$ & $\begin{array}{l}-0.191 \\
(0.548)\end{array}$ & $\begin{array}{l}-0.587 \\
(0.506)\end{array}$ \\
\hline Constant & $\begin{array}{c}-0.779 * * * \\
(0.162)\end{array}$ & $\begin{array}{c}-3.401^{* * *} \\
(0.328)\end{array}$ & $\begin{array}{c}-3.473 * * * \\
(0.260)\end{array}$ & $\begin{array}{c}-0.679 * * * \\
(0.149)\end{array}$ & $\begin{array}{c}-2.361^{* * *} \\
(0.204)\end{array}$ & $\begin{array}{c}-1.578^{* * *} \\
(0.275)\end{array}$ & $\begin{array}{c}1.408^{* * *} \\
(0.208)\end{array}$ & $\begin{array}{c}0.236 \\
(0.317)\end{array}$ & $\begin{array}{c}0.328 \\
(0.272)\end{array}$ \\
\hline Observations & 1,480 & 1,383 & 1,193 & 1,441 & 1,344 & 1,152 & 1,440 & 1,343 & 1,151 \\
\hline Number of groups & 49 & 48 & 48 & 49 & 49 & 48 & 49 & 49 & 48 \\
\hline Within R-squared & 0.556 & 0.592 & 0.638 & 0.576 & 0.598 & 0.586 & 0.677 & 0.619 & 0.627 \\
\hline
\end{tabular}

\footnotetext{
${ }^{14}$ Sudden stops are defined in line with the literature (e.g. Catão, 2006; IMF, 2013), see annex on data sources for definition. Recessions associated with sudden stops are defined as such if a sudden stop occurs two years prior or two years after the recession.

${ }^{15}$ The two variables are correlated as high and sustained CA deficits are more prone to experience sudden stop events (see for instance Cubeddu et al. 2021). The variable 'sustained CA deficit' also includes moderate CA deficits which might not be excessive.

${ }^{16}$ The dummy variable High external debt assumes the value one if the 3-year average of a countries' external gross debt liabilities to GDP prior to the recession year is above the median of the same horizon, by income group. The sample average over time corresponds to 62 percent for AEs and 35 percent for EMs.

${ }^{17}$ The dummy variable High foreign currency exposure assumes the value one if the 3-year average of a countries' foreign currency-denominated debt liabilities to GDP prior to the recession year is above the median of the same horizon, by income group. The sample average over time corresponds to 46 percent for AEs and 31 percent for EMs. Data on foreign currency composition are taken from Benetix et al. 2019
} 
Table 2 summarizes the post-recession impact of internal and external imbalances on external accounts, employing flow and stock vulnerabilities respectively to minimize collinearities.

- External imbalances seem to affect CA balances already in the short term while internal imbalances push up the CA in the medium term. The muted short term effect on the CA is explained by offsetting forces in the saving and investment response.

- Falling investment plays an exceptional role in recessions associated with credit booms. The coefficient is substantially larger than for other vulnerabilities and highly persistent throughout the estimation horizon.

- Recessions associated with credit booms also stand out in the short to medium term saving response, where (public) dissaving dominates instead of (private) deleveraging.

These results are highly robust to including additional controls as exchange rate movements, openness, and relative growth (Annex Table 5).

\section{Globally Synchronized Recessions}

During global crises, a synchronized fall in activity should dampen the improvement in CA balances as global demand slows down in parallel to domestic activity. To test this, we include a global crisis dummy which assumes the value one when more than 25 percent of countries worldwide (GDP-weighted) are in recession (Figure 13). These episodes correspond to the 1974-75 first oil crisis, the 1980 and 1982 second oil crisis/ Latin American debt crisis, the 1991 and 1993 ERM crisis and Gulf crisis, and the 2008-09 Global Financial Crisis (the 2020 COVID-19 crisis is excluded from this sample).

Figure 13: Share of Countries in Recession (in percent, GDP-weighted)



Notes: Horizontal line depicts 25 percent threshold. Average share of recessions (negative real GDP growth country-years) calculated based on GDP-weights, global sample from WEO.

The average CA response during global crises is estimated at around 1 percent of GDP, and therefore significantly lower than during less synchronized recessions (at 2 percent) in the short term, given declining domestic and global demand (Figure 14). As such, exports decline more strongly during global downturns than during idiosyncratic crises. 
Investment to GDP falls somewhat less in synchronized recessions (given fewer investment opportunities abroad during global events), while saving declines more strongly in global recessions (both private and public saving swing widely in global crises: private deleveraging hits 2 percent of GDP and public dissaving 3 percent). The impact of synchronization is highly robust to including pre-existing imbalances in the regression (Annex Table 6) as well as additional controls, reflecting a one-percent lower impact on the CA balance compared with non-synchronized recessions. The difference in the investment response, albeit small, is significant in the multivariate tables, with synchronization implying a less severe decline in investment by around $1 / 2$ percent of GDP.

The CA response to historic recessions in the years 1870 to 1960, which were more synchronized simply because world GDP was relatively concentrated, supports these results. The CA balance shows an improvement of around $1 / 2$ percent initially, increasing to around 1 percent in the longer term, noticeably lower than estimated post-1960s (Annex Figure 8).

Figure 14: Globally Synchronized Recessions
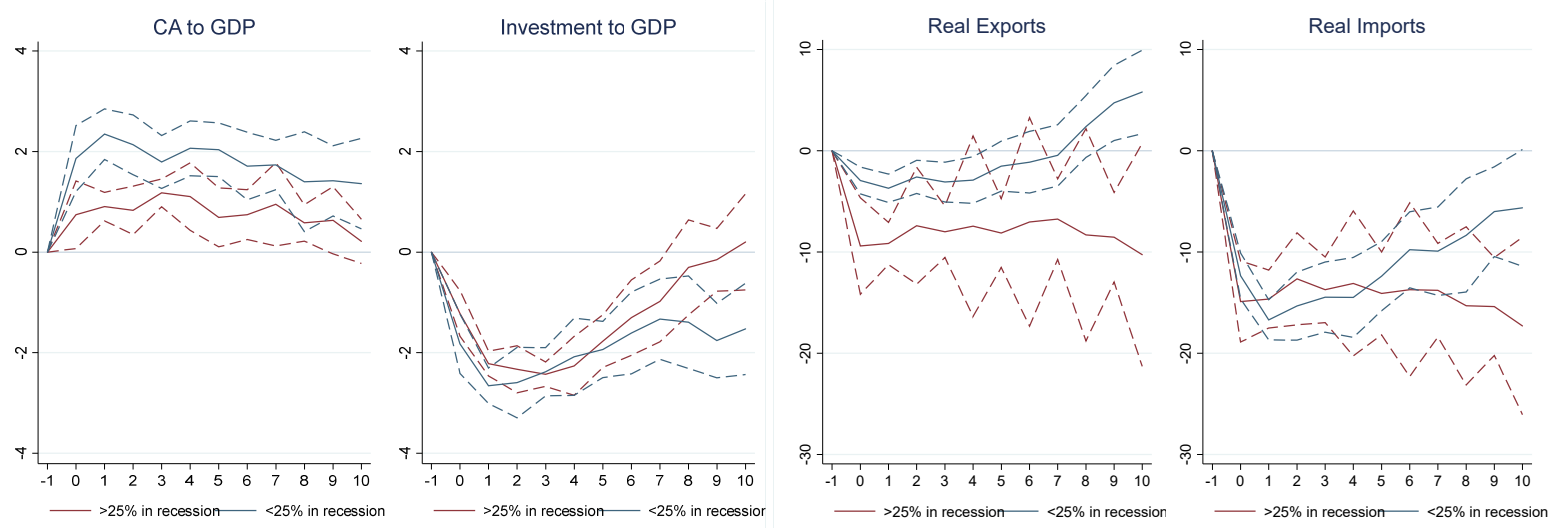

Notes: Cumulative response of CA balances and components in percent of GDP over a 10-year horizon. Dashed lines represent 90 percent confidence interval. Threshold of 25 percent defined as at least (most) 25 percent of countries in recession, GDP-weighted.

\section{Natural Disasters and Epidemics}

Exogenous shocks with an impact on the economy's supply side, such as large natural disasters, tend to temporarily lower the CA balance (IMF 2016). Damages to production and transportation capacity negatively affect exports. Rebuilding the economy, which is often boosted by disaster relief, insurance payments (Laframboise and Loko, 2012), and international aid and remittances in lower/middle income economies (Cabezon et al. 2015), pushes up imports as well as financial inflows.

To empirically test this effect in our framework, we expand the sample to start in 1900 , include about 178 countries and focus on severe natural disasters, using the $75^{\text {th }}$ percentile of the world distribution of mortality rates, which corresponds to 576 events for 
which CA data are available ${ }^{18}$ (see Figure 15 for the distribution of events over time). We find that, shortly after a large natural disaster, CA balances deteriorate by $3 / 4$ percent of GDP, driven by falling exports (Figure 16). The response is relatively short-lived and fades three years after the disaster. Imports rise in the early years, but the effect is not statistically significant.

Figure 15: Number of Severe Epidemics and Natural Disasters

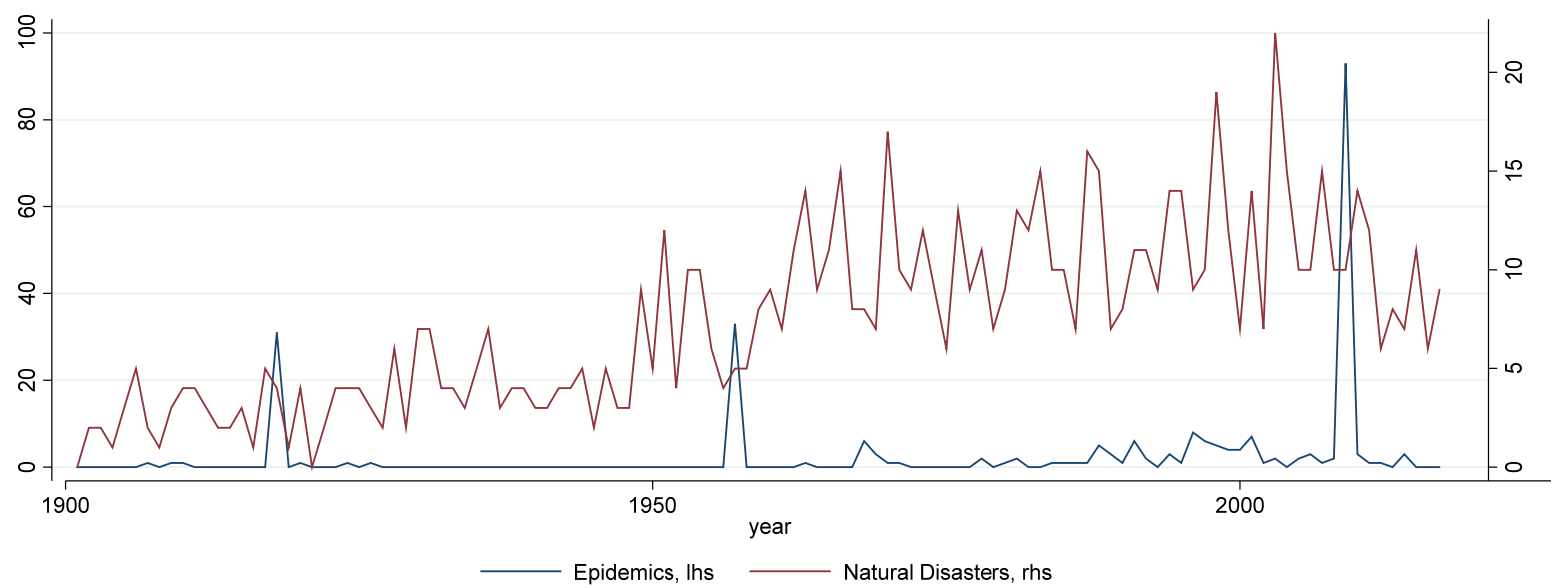

Notes: Chart depicts epidemics and natural disasters with a high impact based on mortality rates, corresponding to the $75^{\text {th }}$ percentile of the world distribution of mortality rates.

Figure 16: CA and Trade Response to Severe Natural Disasters (75th), 1900-2018
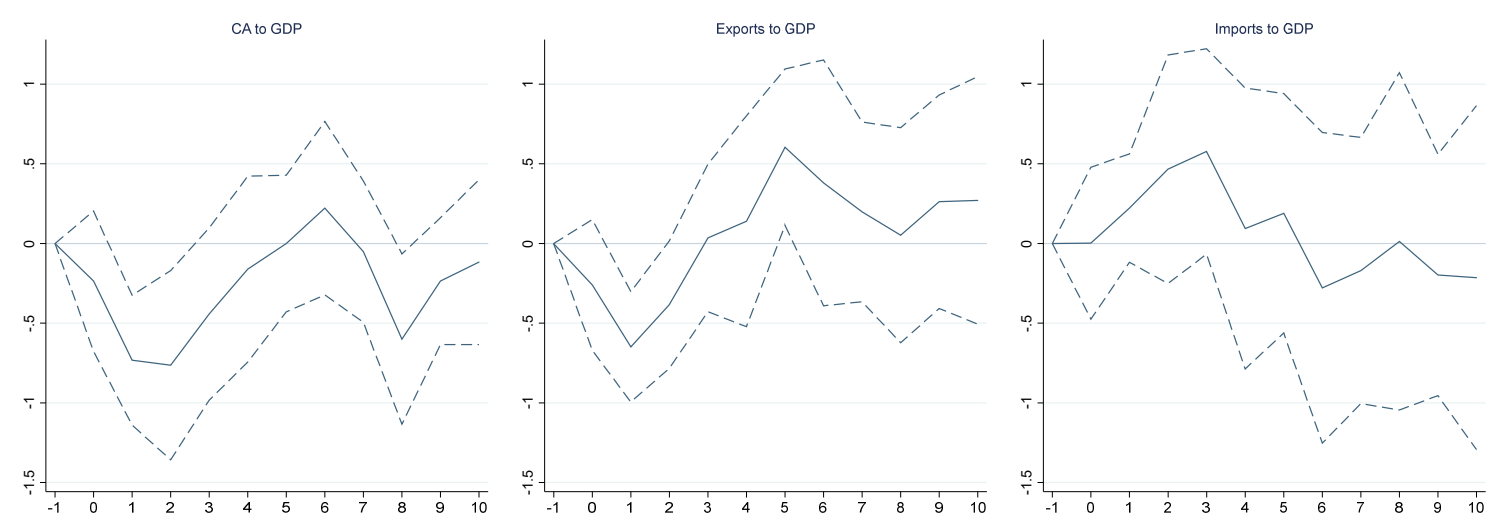

Health crises are exogenous shocks, yet the impact on external balances is more complex, mainly due to underlying strains on the labor force. The short term impact of epidemics could be similar to natural disasters as supply interruptions affect export activity and demand for imports increases, e.g. for medical goods or to substitute domestic goods in case of production fallouts (provided that trading partners are hit asynchronously, see Engler et al. 2020). For the medium to longer term, however, economic theory suggests that

\footnotetext{
${ }^{18}$ For historical data, when only export or import to GDP data are available, we proxy the CA balance by net
} exports to GDP, see also data annex. 
epidemic events exert upward pressures on the external balance as investment demand is likely to fall as labor becomes scarcer, and saving increases due to precautionary motives, rebuilding lost wealth, or forced saving due to mobility restrictions (see Jorda et al. 2020b for the negative impact of epidemics on the natural rate of interest, documented for epidemics dating back to the $14^{\text {th }}$ century). A flood of recent papers on the impact of past (yet more recent) epidemics shows a strong and persistent effect on macroeconomic variables, from output to inequality and labor markets (IMF 2021a, Furceri et al. 2020, Ma et al. 2020), which typically comes with a strong drag on demand and thus, as shown above, an upward adjustment to the CA balance, possibly more than offsetting supply interruptions due to travel, transportation or sick labor force.

Using the historical sample from 1900 onwards with 176 countries (unbalanced) and 252 epidemics of mortality rates above the 75 th percentile cutoff ${ }^{19}$, we find a medium term increase in the CA of 1 to $1 \frac{1}{2}$ percent. Short term fluctuations of the CA response are not significant. Exports to GDP drop initially and pick up towards the end of the horizon while imports to GDP increase immediately during the epidemic ${ }^{20}$ (Figure 17).

Figure 17: CA and Trade Response to Severe Epidemics (75th), 1900-2018
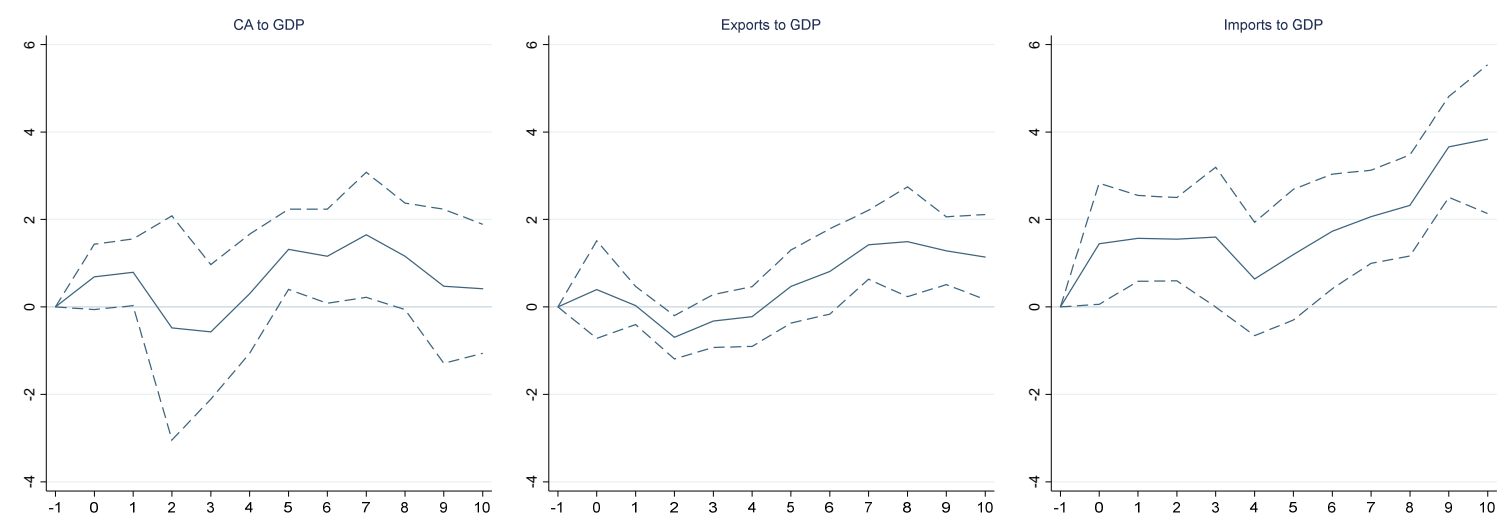

To further study CA components and imbalances, we restrict the sample to our baseline group of countries (i.e. 49 major advanced and emerging markets). This leaves us with a set of 66 epidemics or pandemics with CA data coverage, including the Spanish Flu, the Asian Flu, and the Swine Flu, 37 events for the saving regressions, and 35 events for investment, excluding the Spanish Flu. ${ }^{21}$ The estimations show a significant, short-term dip in

\footnotetext{
${ }^{19}$ The cutoff is equivalent to 5 deaths per 100000 inhabitants. COVID-19 was about 20-40 times as lethal in most countries. Reducing the cutoff to about 5 deaths per 10000 corresponds to the $95^{\text {th }}$ percentile, which would leave us with very few observations only. Using the $90^{\text {th }}$ percentile yields broadly similar results for the global sample for exports and imports to GDP.

${ }^{20}$ Due to uneven data availability, the results on the CA balance, export and import ratio to GDP are not fully compatible.

${ }^{21}$ Severe epidemics or pandemics $\left(75^{\text {th }}\right.$ percentile mortality) with CA data coverage include 14 countries in 1918 during by the Spanish Flu, 17 countries in 1957 during the Asian Flu, 6 in 1968 (Hong Kong Flu), one
}

(continued...) 
the CA during the first year of the epidemic, followed by a strong increase in the CA balance to $1 \frac{1}{2}$ percent of GDP (Figure 18). Dissaving reaches 1 percent of GDP and returns to prerecession levels after three years; investment declines yet with a wide error band.

Figure 18: CA and Trade Response to Severe Epidemics (75th), Major AEs and EMs
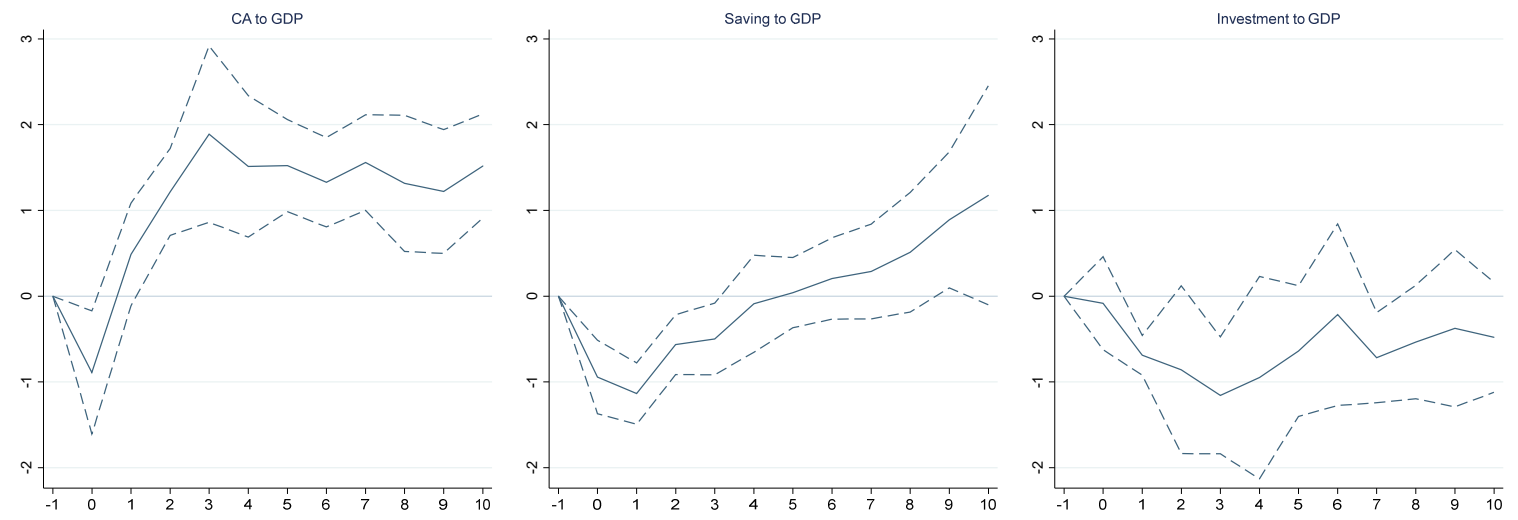

Notes: Cumulative response of CA balances and components in percent of GDP over a 10-year horizon. Dashed lines represent 90 percent confidence interval. Baseline sample with 49 major economies. Severe epidemics (with CA data coverage) amount to 14 in 1918 (Spanish Flu), 17 in 1957 (Asian Flu), 6 in 1968 (HK Flu), 1 in 1991 (Cholera), and 28 in 2009 (Swine Flu/H1N1). Saving and investment panels do not account for epidemices earlier than the 1960s.

Table 3: Determinants of External Adjustment

\begin{tabular}{|c|c|c|c|c|c|c|c|c|c|}
\hline \multirow[b]{3}{*}{ VARIABLES } & \multirow{2}{*}{\multicolumn{3}{|c|}{$\frac{\text { (2) }}{C A}$}} & (4) & $(5)$ & $(6)$ & $(7)$ & (8) & (9) \\
\hline & & & & \multicolumn{3}{|c|}{ Saving } & \multicolumn{3}{|c|}{ Investment } \\
\hline & 1 year & 5 years & 9 years & 1 year & 5 years & 9 years & 1 year & 5 years & 9 years \\
\hline \multirow[t]{2}{*}{ Recession } & 0.616 & -0.419 & 0.373 & $-1.189 * * *$ & $-1.262^{* *}$ & $-2.075^{* *}$ & $-1.975 * * *$ & -0.675 & $-1.666 * * *$ \\
\hline & $(0.494)$ & $(0.523)$ & $(0.526)$ & $(0.449)$ & $(0.557)$ & $(0.835)$ & $(0.257)$ & $(0.488)$ & $(0.554)$ \\
\hline \multirow[t]{2}{*}{ Recession*Credit boom } & 0.365 & $1.475^{* * *}$ & $3.147^{* * *}$ & $-2.701 * * *$ & $-3.404 * * *$ & -0.151 & $-2.431 * * *$ & $-3.846 * * *$ & $-2.901 * * *$ \\
\hline & $(0.441)$ & $(0.403)$ & $(0.535)$ & $(0.443)$ & $(0.783)$ & $(0.501)$ & $(0.484)$ & $(0.497)$ & $(0.443)$ \\
\hline \multirow[t]{2}{*}{ Recession*High public debt } & -0.434 & $1.145^{* * *}$ & 0.754 & $0.727^{* * *}$ & $0.644^{* *}$ & $1.483^{* * *}$ & $1.234 * * *$ & -0.130 & 0.145 \\
\hline & $(0.297)$ & $(0.348)$ & $(0.484)$ & $(0.228)$ & $(0.324)$ & $(0.506)$ & $(0.165)$ & $(0.250)$ & $(0.436)$ \\
\hline \multirow[t]{2}{*}{ Recession*CA deficit } & $1.636^{* * *}$ & $2.123^{* * *}$ & $1.345^{* * *}$ & $1.092^{* * *}$ & $2.228^{* * *}$ & $1.897 * * *$ & $-0.672^{* * *}$ & -0.342 & 0.056 \\
\hline & $(0.404)$ & $(0.365)$ & $(0.501)$ & $(0.371)$ & $(0.341)$ & $(0.331)$ & $(0.243)$ & $(0.534)$ & $(0.584)$ \\
\hline \multirow[t]{2}{*}{ Recession*High external debt } & $0.960^{* * *}$ & $1.084^{* *}$ & $1.081 * * *$ & $0.598^{* *}$ & $1.204^{* * *}$ & 0.609 & -0.252 & -0.068 & -0.411 \\
\hline & $(0.268)$ & $(0.433)$ & $(0.353)$ & $(0.296)$ & $(0.344)$ & (0.619) & $(0.171)$ & (0.539) & $(0.496)$ \\
\hline \multirow[t]{2}{*}{ Recession*Global 25} & $-1.422^{* * *}$ & $-1.392^{* *}$ & $-2.032 * * *$ & $-0.912^{* * *}$ & -0.215 & 1.291 & $1.125^{* * *}$ & $0.889 * *$ & $2.673^{* * *}$ \\
\hline & $(0.364)$ & $(0.629)$ & $(0.612)$ & $(0.307)$ & $(0.797)$ & $(1.017)$ & $(0.243)$ & $(0.368)$ & $(0.482)$ \\
\hline \multirow[t]{2}{*}{ Severe Epidemics } & 0.079 & $1.518^{* * *}$ & $1.334 * * *$ & $-1.204^{* * *}$ & $-0.607^{* *}$ & 0.305 & $-0.857^{* * *}$ & $-2.190 * * *$ & $-0.879 * *$ \\
\hline & $(0.184)$ & $(0.256)$ & $(0.308)$ & (0.179) & $(0.269)$ & $(0.304)$ & $(0.186)$ & $(0.383)$ & $(0.376)$ \\
\hline \multirow[t]{2}{*}{ Constant } & $-0.810 * * *$ & $-3.411 * * *$ & $-3.514^{* * *}$ & $-0.717^{* * *}$ & $-2.375^{* * *}$ & $-1.540^{* * *}$ & $1.418^{* * *}$ & 0.211 & 0.358 \\
\hline & $(0.161)$ & $(0.327)$ & $(0.243)$ & $(0.152)$ & $(0.213)$ & $(0.269)$ & $(0.207)$ & $(0.317)$ & $(0.277)$ \\
\hline Observations & 1,480 & 1,383 & 1,193 & 1,441 & 1,344 & 1,152 & 1,440 & 1,343 & 1,151 \\
\hline Number of groups & 49 & 48 & 48 & 49 & 49 & 48 & 49 & 49 & 48 \\
\hline
\end{tabular}

Standard errors in parentheses

*** $p<0.01,{ }^{* *} p<0.05, * p<0.1$

Including severe epidemics in the multivariate analysis with our baseline sample reduces the number of epidemics further and the results are mainly driven by the 2009 H1N1

country in 1991 hit by the Latin American Cholera outbreak, and 28 countries in 2009 during the Swine Flu/H1N1. Saving and investment coverage is highly unbalanced. 
outbreak. The effects are highly significant for the medium and longer term, despite controlling for prior imbalances and synchronization (Table 3).

\section{HOW IS THIS TIME DIFFERENT?}

Overall, the COVID-19 shock has been one of the most globally synchronized downturns on record, with 80 percent of global GDP in recession, ${ }^{22}$ surpassing the GFC by a small margin (Figure 13). Economies generally entered the 2020 crisis with fewer prior internal and external imbalances: only two countries in the sample show signs of credit booms in the years 2017-2018 and none in 201923 versus 12 in the three years preceding the GFC, and the sum of surpluses and deficits stood at $5 \frac{1}{2}$ percent of global GDP in 2006 against 3 percent in 2019. ${ }^{24}$ In addition, the source of the recession was a pandemic with supply disruptions early in the pandemic affecting trade (Cerdeiro and Komaromi 2020) and sharp sectoral effects on travel, oil, medical products, and consumer goods (IMF 2021b). Together, these factors point towards a moderate impact of the COVID-19 shock on CA balances. Predicting the $2020 \mathrm{CA}$ adjustment based on the above analysis broadly confirms this presumption for economies in recession - on aggregate. Comparing the components, however, the model fails to account for historic shifts in saving, which were driven by unprecedented policy interventions.

Figure 19: COVID-19 Impact on the Current Account for Economies in Recession

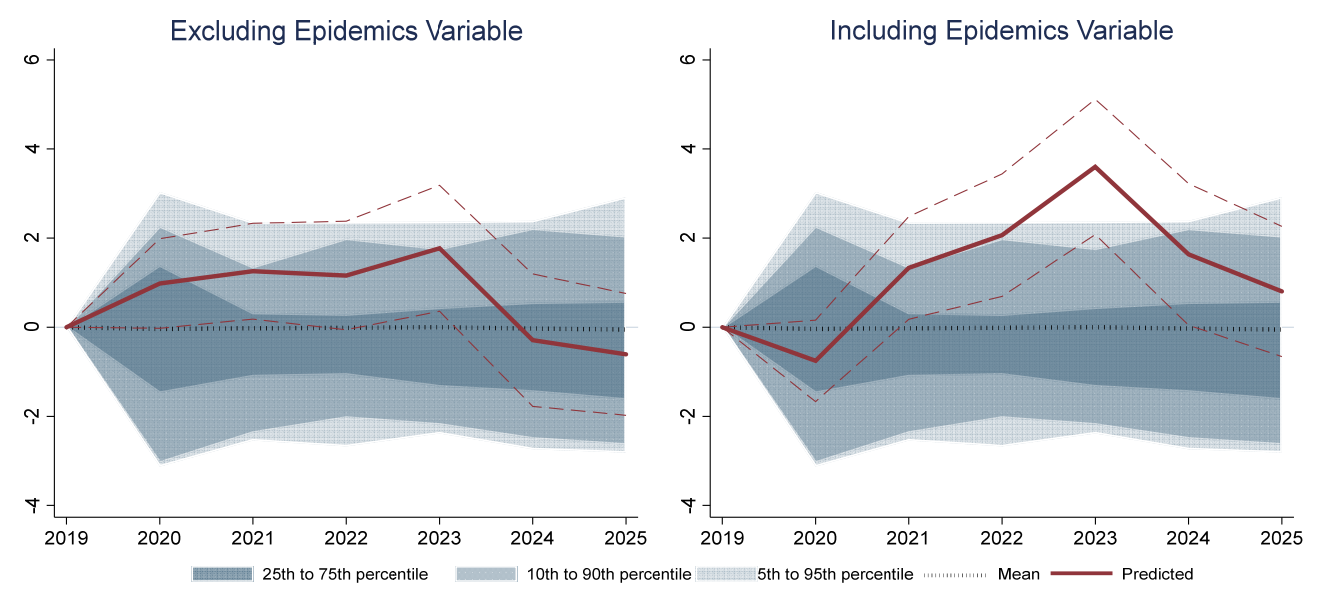

Notes: Data for 2020 are realized and forecasts for 2021 based on IMF 2021 (April WEO). Left panel uses specification as in Annex Table 6 ; right panel uses specification of Table 3 .

\footnotetext{
2247 of the 49 countries in our baseline sample experienced negative real GDP growth in 2020.

${ }^{23}$ As the definition contains metrics relative to the trend, this assessment might change with more data points in the coming years.

${ }^{24}$ Public debt levels were arguably higher in 2019 relative to 2006 (by around 15 percent of GDP), but the increase in debt happened during the GFC and thereafter, rather than in the run-up to the COVID-19 shock. Foreign debt liabilities to GDP were broadly comparable, having increased strongly before the GFC and remained relatively flat thereafter.
} 
Figure 19 displays the predicted path ${ }^{25}$ of the CA balance for the baseline sample based on Table 3 (excluding the epidemics variable (lhs) and including the epidemics variable (rhs), red lines), and the outturn for 2020 for the same set of countries (in blue, IMF forecasts 2021 onwards). In line with smaller (flow) imbalances and the high degree of synchronization, the regression models predict a muted, not statistically significant CA response for recession countries in the short term. Without the epidemics variable (following the specification of Annex Table 6), the model predicts an increase in the CA balance of around 1 percent of GDP. When including epidemics (following the specification of Table 3 ), the CA shows some weakening of around $3 / 4$ percent in the short term. Both specifications predict a statistically significant CA increase in the coming years, however, which is higher when including epidemics and not reflected in current forecasts. The effects are no longer significant after three years into the crisis, mainly explained by a smaller and less persistent decline in investment compared to past recessions. The 2020 outturn for the CA balance was broadly the middle of both predictions: CA balances of recession economies declined by 0.04 percent of GDP, on average. ${ }^{26}$

Figure 20: COVID-19 Impact on Saving for Economies in Recession
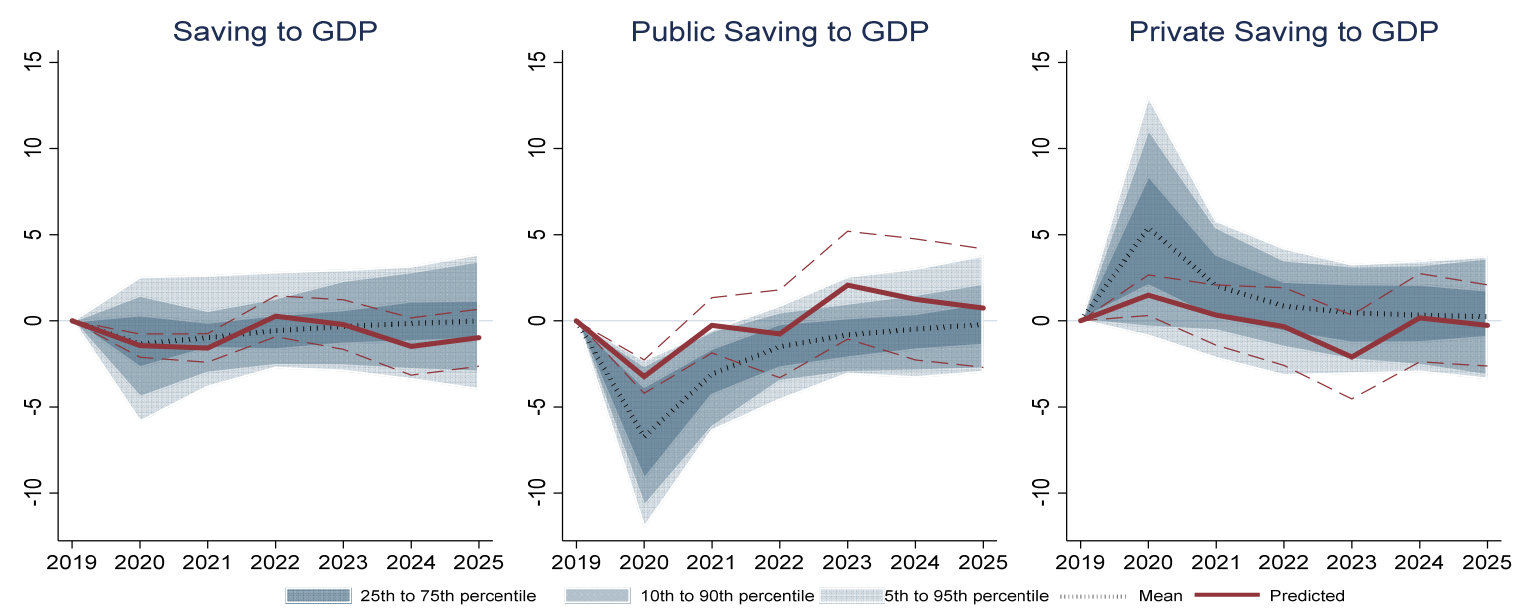

Focusing on the specification without epidemics - given data constraints on subcomponents - the model comes very close to the 2020 realized decline in saving of around $1 \frac{1}{2}$ percent of GDP. Decomposing the saving response, however, offers a very different picture (Figure 20): Public saving declined by 7 percent of GDP on average, against a predicted fall of 3 percent of GDP. The difference is even staker for private saving where

\footnotetext{
${ }^{25}$ To calculate the fitted values, the underlying regression was performed without including the residual from the preceding horizon. Predictions based on regression models excluding the epidemic variable yield highly similar results.

${ }^{26}$ Non-weighted average of the change in the CA balance to GDP for economies in recession. By definition, bar statistical discrepancies, global CA balances in terms of global GDP are multilaterally consistent, i.e. changes in deficits and surpluses must add up to zero.
} 
the outturn reached a record increase of $5 \frac{1}{2}$ percent, more than 3 times higher than evidence from past recessions would have predicted.

These deviations are driven by unprecedented fiscal and monetary policy responses, as well as health crisis-related restrictions, including lockdowns and border closures that prevented travel. Fiscal support during COVID-19 led to a massive expansion of fiscal deficits and thus public dissaving. In several countries government transfers more than compensated income losses for some groups of households. Ample liquidity provision by central banks helped avoid deleveraging by non-financial corporates (and thus also dampen the fall in investment). Lockdowns as well as volunatry social distancing caused a collapse in consumption, in particular for services, and the accumulation of forced saving. Precautionary saving likely rose given heightened job insecurity and health concerns. Together, these interventions helped private saving reach record highs across a broad set of countries, advanced and emerging.

\section{CONCLUSION}

During past recessions, CA balances strengthened significantly and persistently, driven by falling investment and supported by private deleveraging. Pre-existing internal and external imbalances, i.e. excessive private, public, and/or external borrowing, magnified the CA response while countries with larger buffers (e.g. CA surplus economies or countries with lower public debt) were able to use them during recessions, thereby attenuating the fall in investment.

Compared with past experiences, the COVID-19 shock left a very different mark on CA balances. On average, CAs of economies in recession were broadly unchanged ${ }^{27}$, consistent with fewer internal and external imbalances before the crisis and the global nature of the shock. Policy interventions, however, led to unprecedented shifts in savings, with public dissaving more than offsetting record private saving. Going forward, the translation of private saving into consumption, and fiscal (and monetary) policy normalization will have important implications on external balances, in particular if they happen asymmetrically. For instance, rapid dissaving by households driven by pent-up demand and coupled with only gradual return to consolidation by the public sector could temporarly lower CA balances in the respective countries. Should governments be forced to rebuild buffers more quickly, CA balances would increase more in line with the medium term CA improvements we have seen in the past, in particular for those economies with relatively larger vulnerabilities.

Futher asymmetries in the speed of recovery (partly explained by different access to vaccines) could play a role in reshaping external positions across countries. Although average (non-GDP-weighted) CA balances in recession economies were broadly stable,

\footnotetext{
${ }^{27}$ The variance of these changes, however, was higher than usual given the particular nature of shocks (e.g. the travel shock which hit CA balances of tourism economies hard while the counterpart was dispersed across travelers' destination economies).
} 
global imbalances in percent of global GDP increased slightly in 2020 driven by both widening deficits and surpluses in large economies, adding to already high stock imbalances. Finally, as our sample focuses on advanced and non-commodity exporting EMs, more research is needed to better understand the response of external accounts of commodity exporters and lower income economies. 


\section{REFERENCES}

Abiad, Abdul, Petia Topalova, and Prachi Mishra, 2011, "How Does Trade Evolve in the Aftermath of Financial Crises?” IMF Working Paper No. 2011/003 (Washington: International Monetary Fund).

Abiad, Abdul, Daniel Leigh, and Marco E. Terrones, 2010, "Getting the Balance Right: Transitioning out of Sustained Current Account Surpluses," World Economic Outlook, Chapter 4.

Adrian Tobias, Federico Grinberg, Nellie Liang, Sheheryar Malik, Jie Yu 2018, "The Term Structure of Growth-At-Risk," IMF Working Paper No. 18/181 (Washington: International Monetary Fund).

Adrian, Tobias, Nina Boyarchenko, and Domenico Giannone. 2019 "Vulnerable Growth." American Economic Review, 109 (4): 1263-89.

Allen, Cian, 2019. "Revisiting external imbalances: Insights from Sectoral Accounts," Journal of International Money and Finance, Vol. 96(C), pp. 67-101.

Barro, Robert J., Jose F. Ursua, and Joanna Weng, 2020. "The Coronavirus and the Great Influenza Pandemic: Lessons from the "Spanish Flu" for the Coronavirus's Potential Effects on Mortality and Economic Activity". Technical Report 26866, NBER working paper.

Bénétrix, Agustin, Deepali Gautam, Luciana Juvenal, and Martin Schmitz, 2019. “CrossBorder Currency Exposures”, IMF Working Paper No. 19/299 (Washington: International Monetary Fund).

Blanchard, Olivier, Eugenio Cerutti, and Lawrence Summers, 2015. Inflation and Activity Two Explorations and their Monetary Policy Implications. IMF Working Paper No. 15/230 (Washington: International Monetary Fund).

Cabezon, E., L. Hunter, P. Tumbarello, K. Washimi, and Y. Wu, 2015. "Enhancing Macroeconomic Resilience to Natural Disasters and Climate Change in the Small States of the Pacific." IMF Working Paper No. 15/125 (Washington: International Monetary Fund).

Catão, Luis, 2006. "Sudden Stops and Currency Drops: A Historical Look," IMF Working Paper No. 06/133 (Washington: International Monetary Fund).

Cerdeiro, Diego, Andras Komaromi 2020. "Supply Spillovers During the Pandemic: Evidence from High-Frequency Shipping Data", IMF Working Paper No. 20/284 (Washington: International Monetary Fund).

Cerra, Valerie and Sweta Chaman Saxena, 2008. "Growth Dynamics: The Myth of Economic Recovery," American Economic Review, Vol. 98(1), pp. 439-57. 
Cerra, Valerie, Antonio Fatas, and Sweta Chaman Saxena, 2020. "Hysteresis and Business Cycles.” IMF Working Paper No. 20/73 (Washington: International Monetary Fund).

Cubeddu, Luis, Swarnali Ahmed Hannan, and Pau Rabanal. 2021 "External Financing Risks: How Important is the Composition of the International Investment Position?" IMF Working Paper No. 2021/020, https://ssrn.com/abstract=3799612 (Washington: International Monetary Fund).

Dell'Ariccia, Giovanni, Ehsan Ebrahimy, Deniz Igan, and Damien Puy, 2020. "Discerning Good from Bad Credit Booms: The Role of Construction," IMF Staff Discussion Note No. SDN/20/02.

Engler, Philipp, Nathalie Pouokam, Diego Rodriguez Guzman, and Irina Yakadina, 2020. "The Great Lockdown: International Risk Sharing Through Trade and Policy Coordination" IMF Working Paper No. 20/242 (Washington: International Monetary Fund).

Freund, Caroline and Frank Warnock (2007), "Current Account Deficits in Industrial Countries: The Bigger They Are, the Harder They Fall?” in Richard Clarida (ed.), G7 Current Account Imbalances: Sustainability and Adjustment, University of Chicago Press.

IMF 2016. IMF Policy Paper, "Small States' Resilience to Natural Disasters and Climate Change-Role for the IMF."

IMF 2021a. "World Economic Outlook: Managing Divergent Recoveries.” April 2021, International Monetary Fund, Washington, DC.

IMF 2021b. External Sector Report, International Monetary Fund, Washington, DC.

Jorda, Oscar, 2005, "Estimation and Inference of Impulse Responses by Local Projections," American Economic Review, Vol. 95 (1): 161-82.

Jordà, Oscar, Moritz Schularick, and Alan M. Taylor. 2017. "Macrofinancial History and the New Business Cycle Facts." in NBER Macroeconomics Annual 2016, volume 31, edited by Martin Eichenbaum and Jonathan A. Parker. Chicago: University of Chicago Press.

Jordà, Òscar, Martin Kornejew, Moritz Schularick, and Alan M. Taylor. 2020a. "Zombies at Large? Corporate Debt Overhang and the Macroeconomy," Federal Reserve Bank of San Francisco Working Paper 2020-36. https://doi.org/10.24148/wp2020-36.

Jordà, Òscar, Sanjay Singh, and Alan M. Taylor, 2020b. "Longer-Run Economic Consequences of Pandemics”, Federal Reserve Bank of San Francisco, Working Paper 2020-09 https://doi.org/10.24148/wp2020-09.

Laeven, Luc and Fabian Valencia, 2020, "Systemic Banking Crises Database II". IMF Econ Rev 68, 307-361 (2020). https://doi.org/10.1057/s41308-020-00107-3. 
Laframboise, N., and B. Loko, 2012, "Natural Disasters: Mitigating Impact, Managing Risks.” IMF Working Paper No. 12/245 (Washington: International Monetary Fund).

Lane, Philip R. and Milesi-Ferretti, Gian Maria 2012. External adjustment and the global crisis. Journal of International Economics, 88(2): 252-65.

Li, Nan and Mattia Coppo, 2020, "Severe Epidemics in Modern History: Growth, Debt and Civil Unrest,” IMF Research Department Special Series on COVID-19.

Ma, Chang, John H. Rogers, and Sili Zhou. 2020. "Modern Pandemics: Recession and Recovery," BOFIT Discussion Paper No. 16, https://ssrn.com/abstract=3565646.

Milesi-Ferretti, Gian Maria, and Assaf Razin 1998. "Current Account Reversals and Currency Crises: Empirical Regularities,” NBER Working Paper 6620.

Teulings, Coen N., and Nikolay Zubanov, 2014, "Is Economic Recovery a Myth? Robust Estimation of Impulse Responses," Journal of Applied Econometrics, Vol. 29, No. 3, pp. 497-514. 
Annex

\section{Data sources}

- Macroeconomic data, including the current account balance and its components, public debt, exchange rates, and relative growth, are from IMF IFS over the period 1960 to 2020. Data on household and non-financial corporate saving are taken from the OECD national accounts statistics database.

- Credit booms are based on Dell'Ariccia et al. 2020 and defined as episode during which the ratio of credit to GDP grows faster than implied by its past trend, with the deviation from trend greater than 1.5 times its standard deviation and the annual growth rate of the credit to-GDP ratio exceeding 10 percent; or the annual growth rate of the credit-to-GDP ratio exceeding 20 percent covering 1970-2016.

- Banking crises are from Laeven and Valencia 2020, covering 1970-2017.

- Sudden stops are defined, in line with the literature (Catão, 2006), as episodes when net private capital inflows are $1 \frac{1}{2}$ standard deviation below their mean and the annual decline is $3 / 4$ standard deviations from a year earlier (defined in real U.S. dollars); or have declined by at least 3 percentage points of GDP relative to the previous year and 2 percentage points from two years earlier, covering 1991-2018.

- External liabilities are from the Lane and Milesi-Feretti database on the External Wealth of Nations and foreign currency composition is based on Benetix et al. 2019.

- Historic data on current account, exports and imports to GDP are based on Jordà et al. 2017 (covering 17 countries, 1870-2016, unbalanced). Where current account data are not available but data points on exports and imports to GDP exist, we proxy the current account by net exports.

- Natural disasters are taken from the EM-DAT database by the Centre for Research on the Epidemiology of Disasters (CRED) and cover the years 1900-2019

- Epidemics are taken from Li and Coppo 2020, based on WHO, ECDC/CDC, and Journal of Infectious Diseases and cover the years 1900-2019. 


\section{Annex Figure 1: Sectoral Response to Recessions}
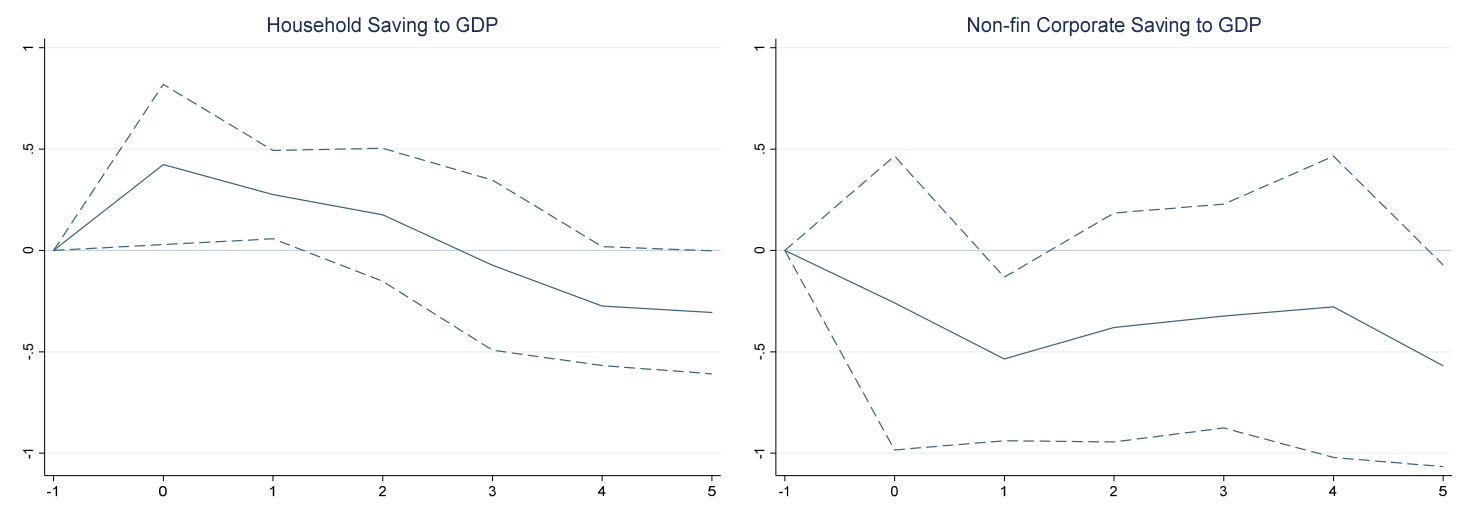

Notes: Cumulative response in percent of GDP over a 5-year horizon. Dashed lines represent 90 percent confidence interval.

Annex Figure 2: CA sensitivity over time, 5 year response to recessions, 5 year window

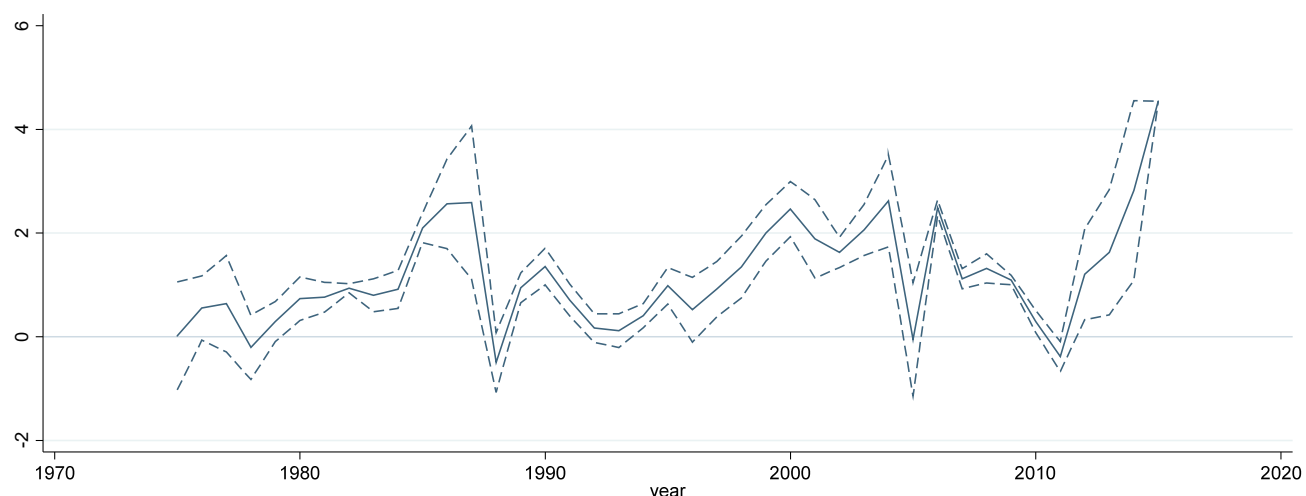

Annex Figure 3: Trade Response By Income Group (Non-commodity EMs only)
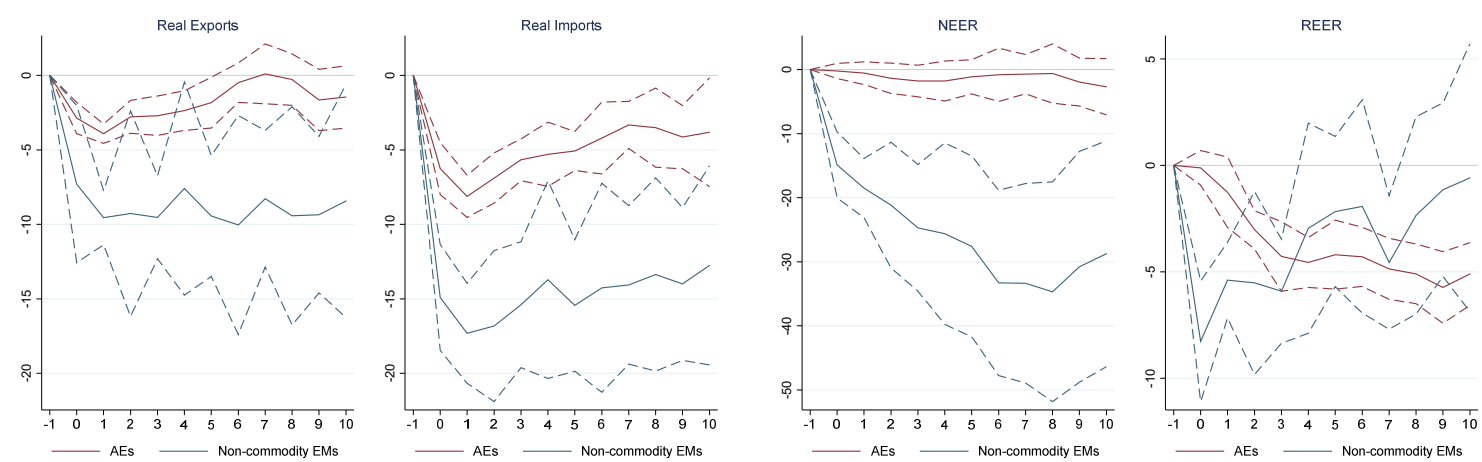

Notes: Cumulative response of trade and exchange rates in percent over a 10-year horizon by country group. Dashed lines represent 90 percent confidence interval. Responses of AEs and non-commodity EMs are estimated in split samples. 


\section{Annex Figure 4: Recessions Associated with Banking crises}
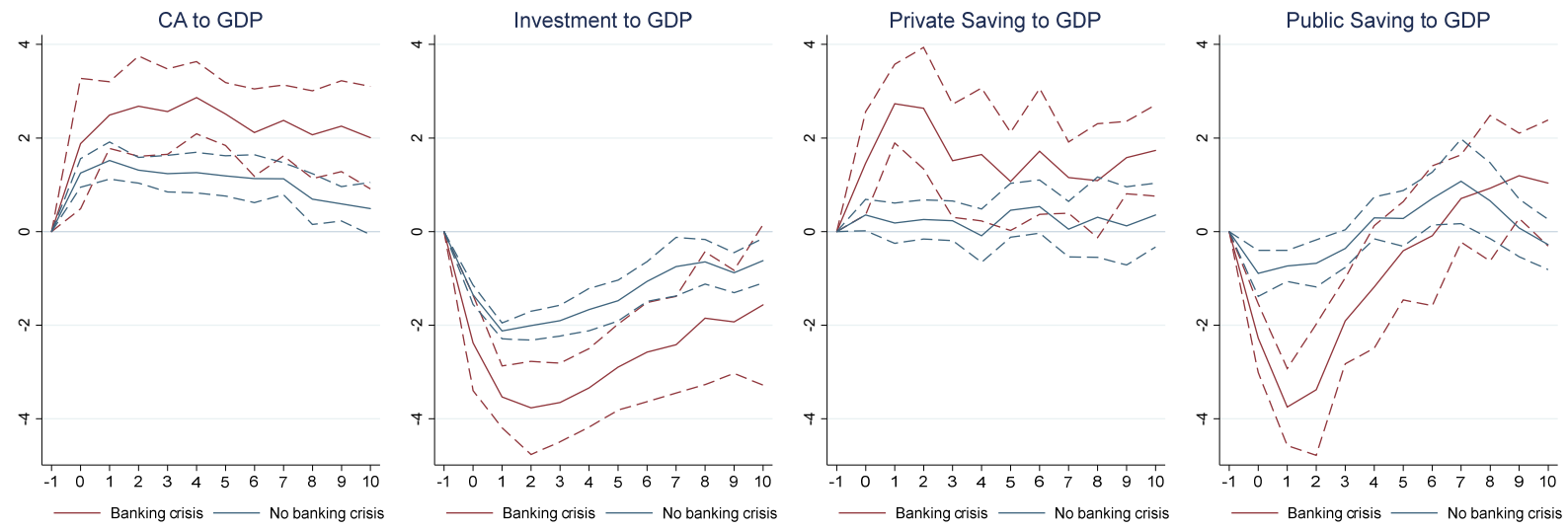

Notes: Cumulative response of CA balances and components in percent of GDP over a 10-year horizon. Dashed lines represent 90 percent confidence interval. Banking crises are taken from Laeven and Valencia (2020), covering the period 1970-2017.

\section{Annex Figure 5: Density of Public Debt to GDP By Income Group}
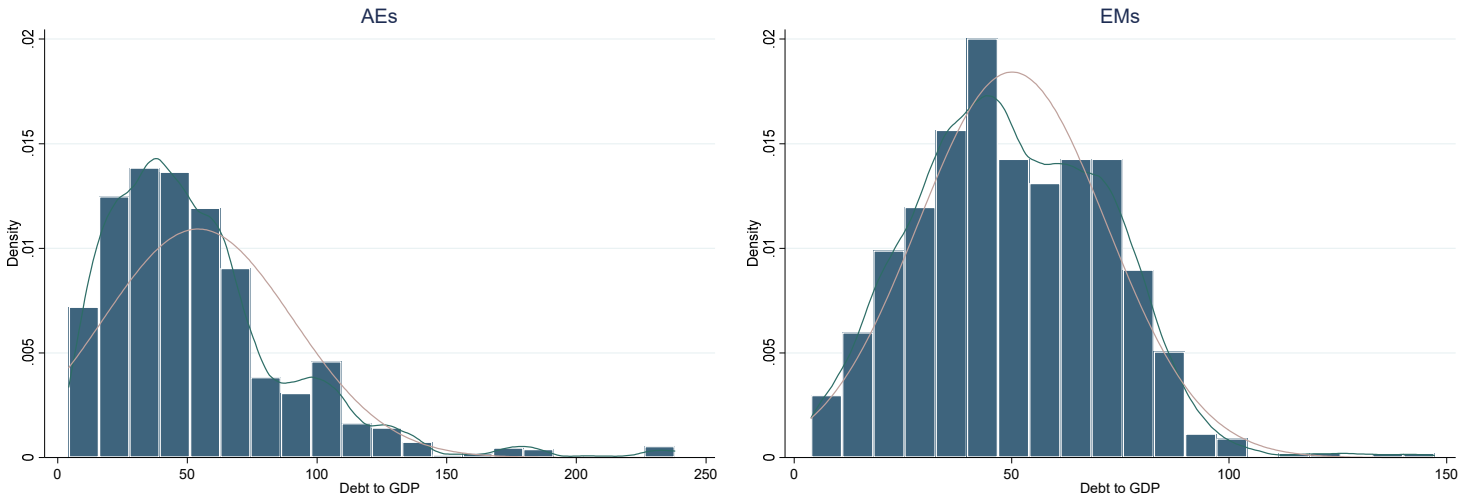

Notes: Lines depict normal density curve (rose) and kernal density estimate (green). AE and EM densities seem surprisingly similar around the mean of 50 percent, which is explained by the unbalanced time horizon. Most AE debt series start in the 1960s when public debt was relatively low while EM debt series are populated from the 1990s onwards.

\section{Annex Figure 6: Recessions Associated with Sudden Stops}
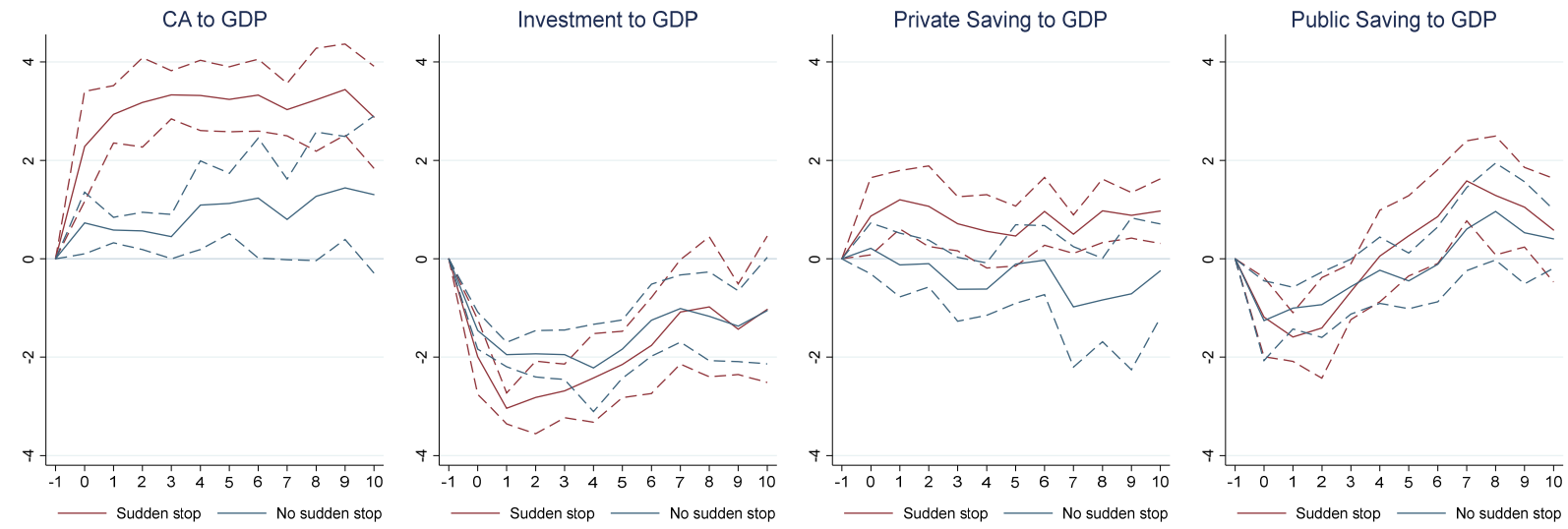


\section{Annex Figure 7: Recessions and High Foreign Debt Liabilities}
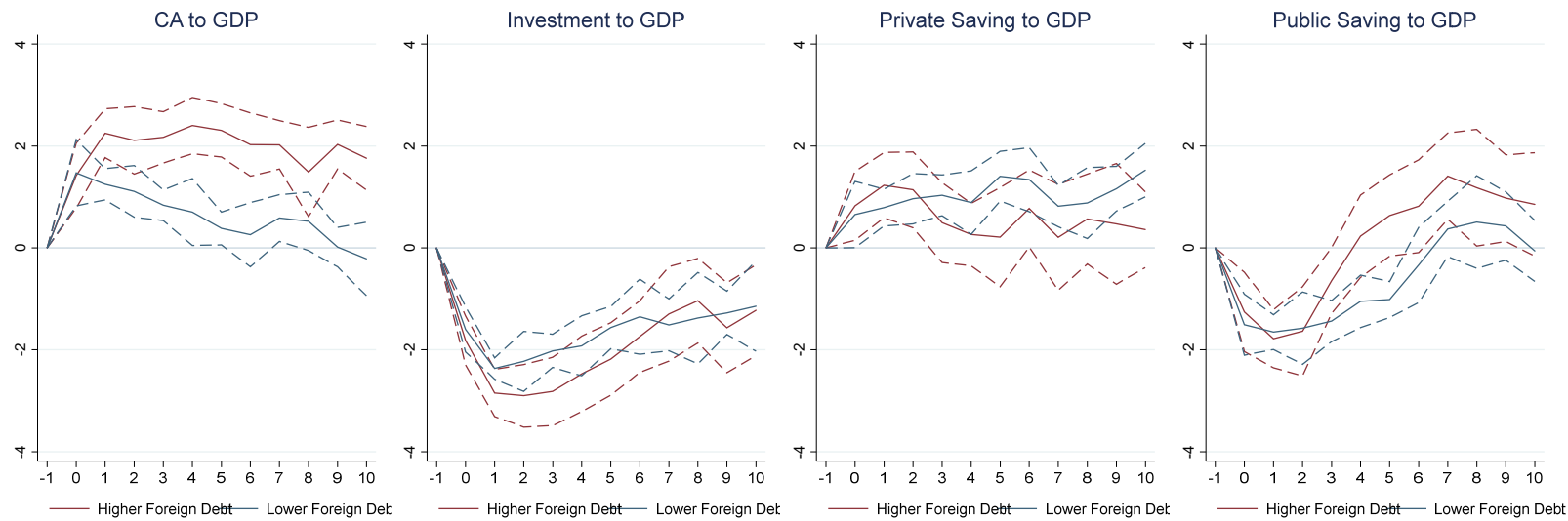

Annex Figure 8: Historical Response to Recessions, 1870-1960
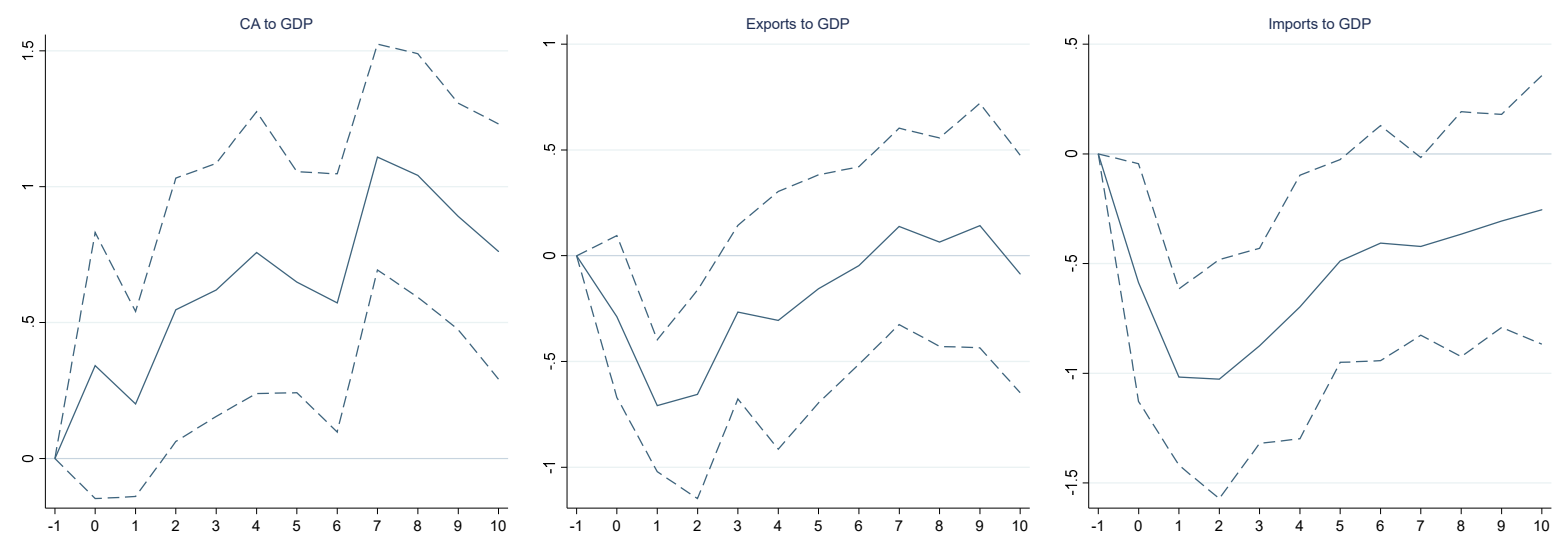

Notes: Cumulative response of CA balances and components in percent of GDP over a 10-year horizon. Dashed lines represent 90 percent confidence interval, estimated with Cook's distance correction. Estimations cover 375 recession country-years, defined as negative real GDP growth, based on historical data from Jorda et al. 2017. 
Annex Table 1: Sample Economies

\begin{tabular}{|c|c|c|c|c|}
\hline Baseline Sample & $\begin{array}{l}\text { Advanced } \\
\text { Economies }\end{array}$ & $\begin{array}{l}\text { Non-commodity } \\
\text { Emerging Markets }\end{array}$ & $\begin{array}{l}\text { Commodity } \\
\text { Emerging Markets }\end{array}$ & $\begin{array}{l}\text { Historical Sample } \\
(1870-2016)\end{array}$ \\
\hline Argentina & Australia & Belarus & Algeria & Australia \\
\hline Australia & Austria & Brazil & Angola & Belgium \\
\hline Austria & Belgium & China & Argentina & Canada \\
\hline Belgium & Canada & Colombia & Azerbaijan & Denmark \\
\hline Brazil & Cyprus & Costa Rica & Chile & Finland \\
\hline Canada & Czech Republic & Croatia & Ecuador & France \\
\hline Chile & Denmark & Dominican Republic & Iran & Germany \\
\hline China & Estonia & Egypt & Kazakhstan & Italy \\
\hline Colombia & Finland & Guatemala & Kuwait & Japan \\
\hline Costa Rica & France & Hungary & Libya & Netherlands \\
\hline Czech Republic & Germany & India & Oman & Norway \\
\hline Denmark & Greece & Indonesia & Peru & Portugal \\
\hline Egypt & Hong Kong SAR & Malaysia & Qatar & Spain \\
\hline Finland & Iceland & Mexico & Russia & Sweden \\
\hline France & Ireland & Morocco & Saudi Arabia & Switzerland \\
\hline Germany & Israel & Pakistan & South Africa & United Kingdom \\
\hline Greece & Italy & Philippines & United Arab Emirates & United States \\
\hline Guatemala & Japan & Poland & Uruguay & \\
\hline Hungary & Korea & Romania & Venezuela & \\
\hline India & Latvia & Sri Lanka & & \\
\hline Indonesia & Lithuania & Thailand & & \\
\hline Ireland & Luxembourg & Tunisia & & \\
\hline Israel & Netherlands & Turkey & & \\
\hline Italy & New Zealand & Ukraine & & \\
\hline Japan & Norway & & & \\
\hline Korea & Portugal & & & \\
\hline Malaysia & Singapore & & & \\
\hline Mexico & Slovak Republic & & & \\
\hline Morocco & Slovenia & & & \\
\hline Netherlands & Sweden & & & \\
\hline New Zealand & Spain & & & \\
\hline Norway & Switzerland & & & \\
\hline Pakistan & Taiwan Province c & & & \\
\hline Peru & United Kingdom & & & \\
\hline Philippines & United States & & & \\
\hline \multicolumn{5}{|l|}{ Poland } \\
\hline \multicolumn{5}{|l|}{ Portugal } \\
\hline \multicolumn{5}{|l|}{ Russia } \\
\hline \multicolumn{5}{|l|}{ South Africa } \\
\hline \multicolumn{5}{|l|}{ Spain } \\
\hline \multicolumn{5}{|l|}{ Sri Lanka } \\
\hline \multicolumn{5}{|l|}{ Sweden } \\
\hline \multicolumn{5}{|l|}{ Switzerland } \\
\hline \multicolumn{5}{|l|}{ Thailand } \\
\hline \multicolumn{5}{|l|}{ Tunisia } \\
\hline \multicolumn{5}{|l|}{ Turkey } \\
\hline \multicolumn{5}{|l|}{ United Kingdom } \\
\hline \multicolumn{5}{|l|}{ United States } \\
\hline Uruguay & & & & \\
\hline
\end{tabular}


Annex Table 2: Current Account, Saving, and Investment in AEs and Non-commodity EMs

\begin{tabular}{|c|c|c|c|c|c|c|c|c|c|c|c|c|}
\hline \multirow[b]{3}{*}{ VARIABLES } & (1) & (2) & (3) & (4) & (5) & (6) & (7) & (8) & (9) & (10) & (11) & (12) \\
\hline & \multicolumn{2}{|c|}{ CA } & \multicolumn{2}{|c|}{ Saving } & \multicolumn{2}{|c|}{ Investment } & \multicolumn{2}{|c|}{ CA } & \multicolumn{2}{|c|}{ Saving } & \multicolumn{2}{|c|}{ Investment } \\
\hline & 1 year & 9 years & 1 year & 9 years & 1 year & 9 years & 1 year & 9 years & 1 year & 9 years & 1 year & 9 years \\
\hline Recession & $\begin{array}{c}1.738^{* * *} \\
(0.273)\end{array}$ & $\begin{array}{c}1.750^{* * *} \\
(0.414)\end{array}$ & $\begin{array}{c}-1.058^{* * *} \\
(0.152)\end{array}$ & $\begin{array}{c}0.820 * * * \\
(0.318)\end{array}$ & $\begin{array}{c}-2.546 * * * \\
(0.157)\end{array}$ & $\begin{array}{c}-0.929^{* *} \\
(0.384)\end{array}$ & $\begin{array}{c}0.818^{* * *} \\
(0.270)\end{array}$ & $\begin{array}{c}1.902^{* * *} \\
(0.409)\end{array}$ & $\begin{array}{l}-0.303 \\
(0.220)\end{array}$ & $\begin{array}{c}0.819^{* *} \\
(0.332)\end{array}$ & $\begin{array}{c}-1.000^{* * *} \\
(0.155)\end{array}$ & $\begin{array}{c}-0.887^{* * *} \\
(0.313)\end{array}$ \\
\hline Recession*EM & $\begin{array}{c}0.284 \\
(0.491)\end{array}$ & $\begin{array}{c}-1.416^{* *} \\
(0.625)\end{array}$ & $\begin{array}{l}-0.065 \\
(0.327)\end{array}$ & $\begin{array}{c}-2.436 * * * \\
(0.390)\end{array}$ & $\begin{array}{l}-0.316 \\
(0.365)\end{array}$ & $\begin{array}{l}-0.184 \\
(0.578)\end{array}$ & $\begin{array}{l}-0.590 \\
(0.511)\end{array}$ & $\begin{array}{c}-1.609^{* *} \\
(0.744)\end{array}$ & $\begin{array}{c}0.368 \\
(0.313)\end{array}$ & $\begin{array}{c}-2.654^{* * *} \\
(0.505)\end{array}$ & $\begin{array}{c}0.686 * * \\
(0.293)\end{array}$ & $\begin{array}{l}-0.493 \\
(0.525)\end{array}$ \\
\hline$\Delta$ Exchange rate & & & & & & & $\begin{array}{c}-0.016 * * \\
(0.007)\end{array}$ & $\begin{array}{c}0.001 \\
(0.008)\end{array}$ & $\begin{array}{c}-0.015^{* *} \\
(0.006)\end{array}$ & $\begin{array}{l}-0.007 \\
(0.008)\end{array}$ & $\begin{array}{c}0.014 \\
(0.014)\end{array}$ & $\begin{array}{l}-0.007 \\
(0.014)\end{array}$ \\
\hline Openness & & & & & & & $\begin{array}{l}-0.000 \\
(0.003)\end{array}$ & $\begin{array}{l}-0.003 \\
(0.006)\end{array}$ & $\begin{array}{c}0.002 \\
(0.002)\end{array}$ & $\begin{array}{l}-0.005 \\
(0.004)\end{array}$ & $\begin{array}{c}0.003 \\
(0.003)\end{array}$ & $\begin{array}{l}-0.010 \\
(0.008)\end{array}$ \\
\hline Relative growth & & & & & & & $\begin{array}{c}-0.227^{* * *} \\
(0.034)\end{array}$ & $\begin{array}{l}-0.057 \\
(0.037)\end{array}$ & $\begin{array}{c}0.194^{* * *} \\
(0.029)\end{array}$ & $\begin{array}{c}0.001 \\
(0.039)\end{array}$ & $\begin{array}{c}0.372^{* * *} \\
(0.032)\end{array}$ & $\begin{array}{c}0.071 \\
(0.045)\end{array}$ \\
\hline Constant & $\begin{array}{c}-0.156^{* *} \\
(0.071)\end{array}$ & $\begin{array}{c}1.134^{* * *} \\
(0.111)\end{array}$ & $\begin{array}{c}0.003 \\
(0.159)\end{array}$ & $\begin{array}{c}3.013^{* * *} \\
(0.259)\end{array}$ & $\begin{array}{c}1.422^{* * *} \\
(0.091)\end{array}$ & $\begin{array}{c}3.757^{* * *} \\
(0.195)\end{array}$ & $\begin{array}{c}1.636^{* * *} \\
(0.238)\end{array}$ & $\begin{array}{c}2.363^{* * *} \\
(0.535)\end{array}$ & $\begin{array}{c}-1.731 * * * \\
(0.163)\end{array}$ & $\begin{array}{c}2.274^{* * *} \\
(0.361)\end{array}$ & $\begin{array}{c}-0.574 * * * \\
(0.213)\end{array}$ & $\begin{array}{l}-0.659 \\
(0.586)\end{array}$ \\
\hline Observations & 2,597 & 2,141 & 2,567 & 2,111 & 2,631 & 2,175 & 2,035 & 1,579 & 2,067 & 1,611 & 2,067 & 1,611 \\
\hline Number of groups & 57 & 57 & 57 & 57 & 57 & 57 & 57 & 57 & 57 & 57 & 57 & 57 \\
\hline Within R-squared & 0.528 & 0.545 & 0.507 & 0.520 & 0.616 & 0.582 & 0.525 & 0.539 & 0.536 & 0.537 & 0.626 & 0.568 \\
\hline
\end{tabular}

Annex Table 3: The Role of Internal Imbalances, Additional Controls

\begin{tabular}{|c|c|c|c|c|c|c|c|c|c|}
\hline \multirow[b]{3}{*}{ VARIABLES } & $(1)$ & (2) & (3) & (4) & $(5)$ & $(6)$ & $(7)$ & $(8)$ & (9) \\
\hline & \multicolumn{3}{|c|}{$\mathrm{CA}$} & \multicolumn{3}{|c|}{ Saving } & \multicolumn{3}{|c|}{ Investment } \\
\hline & 1 year & 5 years & 9 years & 1 year & 5 years & 9 years & 1 year & 5 years & 9 years \\
\hline \multirow[t]{2}{*}{ Recession } & 0.053 & -0.201 & 0.463 & -0.284 & 0.329 & -0.309 & $-0.593 * *$ & 0.344 & -0.463 \\
\hline & (0.319) & $(0.363)$ & $(0.342)$ & $(0.208)$ & $(0.350)$ & $(0.490)$ & $(0.235)$ & $(0.347)$ & $(0.349)$ \\
\hline \multirow[t]{2}{*}{ Recession*credit boom } & $0.814^{*}$ & $2.542^{* * *}$ & $4.532^{* * *}$ & $-2.008^{* * *}$ & $-2.069 * * *$ & 0.557 & $-2.192^{* * *}$ & $-3.866 * * *$ & $-3.504 * * *$ \\
\hline & $(0.437)$ & $(0.354)$ & $(0.618)$ & $(0.418)$ & $(0.675)$ & $(0.514)$ & $(0.553)$ & $(0.483)$ & $(0.496)$ \\
\hline \multirow[t]{2}{*}{ Recession*high debt } & 0.156 & $1.885^{* * *}$ & $1.177^{* *}$ & $1.093^{* * *}$ & $1.295^{* * *}$ & $1.450 * * *$ & $1.025^{* * *}$ & -0.404 & -0.120 \\
\hline & $(0.350)$ & $(0.429)$ & $(0.527)$ & $(0.276)$ & $(0.377)$ & $(0.550)$ & $(0.159)$ & $(0.248)$ & $(0.435)$ \\
\hline \multirow[t]{2}{*}{$\Delta$ Exchange rate } & $-0.024 * *$ & -0.007 & $0.021 * *$ & $-0.024 * * *$ & -0.012 & 0.015 & 0.008 & 0.008 & 0.011 \\
\hline & $(0.010)$ & $(0.017)$ & $(0.011)$ & $(0.005)$ & $(0.014)$ & $(0.016)$ & $(0.009)$ & $(0.015)$ & $(0.014)$ \\
\hline \multirow[t]{2}{*}{ Openness } & $0.034 * * *$ & $0.045^{* * *}$ & 0.021 & $0.036^{* * *}$ & $0.060 * * *$ & 0.025 & 0.004 & 0.019 & 0.018 \\
\hline & $(0.005)$ & $(0.010)$ & $(0.013)$ & $(0.006)$ & $(0.011)$ & $(0.020)$ & $(0.003)$ & $(0.012)$ & $(0.013)$ \\
\hline \multirow[t]{2}{*}{ Relative Growth } & $-0.369 * * *$ & $-0.344 * * *$ & $-0.203^{* * *}$ & $0.103 * * *$ & -0.033 & -0.178 & $0.389 * * *$ & $0.273 * * *$ & -0.002 \\
\hline & $(0.034)$ & $(0.061)$ & $(0.079)$ & $(0.036)$ & $(0.067)$ & (0.109) & $(0.042)$ & $(0.043)$ & $(0.064)$ \\
\hline \multirow[t]{2}{*}{ Constant } & $-1.502^{* * *}$ & $-2.683 * * *$ & 0.000 & $-2.827^{* * *}$ & $-3.250 * * *$ & 0.000 & $-1.471^{* * *}$ & $-4.534 * * *$ & 0.000 \\
\hline & $(0.299)$ & $(0.652)$ & $(0.000)$ & $(0.389)$ & $(0.826)$ & $(0.000)$ & $(0.259)$ & $(0.758)$ & $(0.000)$ \\
\hline Observations & 1,324 & 1,227 & 1,037 & 1,327 & 1,230 & 1,036 & 1,330 & 1,233 & 1,039 \\
\hline Number of groups & 49 & 48 & 48 & 49 & 49 & 49 & 49 & 49 & 49 \\
\hline Within R-squared & 0.549 & 0.553 & 0.585 & 0.575 & 0.598 & 0.592 & 0.683 & 0.614 & 0.604 \\
\hline
\end{tabular}


Annex Table 4: The Role of External Imbalances, Additional Controls

\begin{tabular}{|c|c|c|c|c|c|c|c|c|c|}
\hline \multirow[b]{3}{*}{ VARIABLES } & \multirow{2}{*}{\multicolumn{3}{|c|}{$\frac{\text { (2) }}{\mathrm{CA}}$}} & (4) & $(5)$ & (6) & (7) & $(8)$ & (9) \\
\hline & & & & \multicolumn{3}{|c|}{ Saving } & \multicolumn{3}{|c|}{ Investment } \\
\hline & 1 year & 5 years & 9 years & 1 year & 5 years & 9 years & 1 year & 5 years & 9 years \\
\hline \multirow[t]{2}{*}{ Recession } & -0.559 & $-0.631^{* * *}$ & 0.085 & -0.369 & $-0.536^{*}$ & $-1.299 * * *$ & -0.280 & -0.172 & $-1.607 * *$ \\
\hline & $(0.360)$ & $(0.238)$ & $(0.511)$ & $(0.387)$ & $(0.309)$ & $(0.356)$ & $(0.312)$ & $(0.415)$ & $(0.658)$ \\
\hline \multirow[t]{2}{*}{ Recession*CA deficit } & $1.043^{* *}$ & $1.057^{* * *}$ & 0.616 & $0.684^{* *}$ & $1.108^{* * *}$ & $1.608^{* * *}$ & -0.303 & 0.435 & 1.027 \\
\hline & $(0.446)$ & $(0.377)$ & $(0.793)$ & $(0.330)$ & $(0.325)$ & $(0.451)$ & $(0.310)$ & $(0.490)$ & $(0.826)$ \\
\hline \multirow[t]{2}{*}{ Recession*high external debt } & 0.140 & $0.894^{* *}$ & $1.232^{* * *}$ & -0.572 & 0.054 & $-0.949 *$ & -0.011 & -0.622 & $-1.039 *$ \\
\hline & $(0.303)$ & $(0.347)$ & $(0.328)$ & $(0.351)$ & $(0.378)$ & $(0.543)$ & $(0.375)$ & $(0.590)$ & $(0.627)$ \\
\hline \multirow[t]{2}{*}{$\Delta$ Exchange rate } & -0.003 & $0.006^{*}$ & $0.014^{* * *}$ & -0.001 & $0.009 * * *$ & $0.017^{* * *}$ & 0.002 & 0.002 & -0.000 \\
\hline & $(0.003)$ & $(0.003)$ & $(0.002)$ & $(0.003)$ & $(0.003)$ & $(0.003)$ & $(0.003)$ & $(0.005)$ & $(0.004)$ \\
\hline \multirow[t]{2}{*}{ Openness } & $0.014 * *$ & $0.028^{* * *}$ & $0.049 * * *$ & $0.018^{* * *}$ & $0.022^{*}$ & -0.000 & 0.006 & -0.001 & $-0.056 * * *$ \\
\hline & $(0.006)$ & $(0.009)$ & $(0.007)$ & $(0.006)$ & $(0.012)$ & (0.014) & $(0.004)$ & $(0.011)$ & $(0.018)$ \\
\hline \multirow[t]{2}{*}{ Relative Growth } & $-0.237 * * *$ & $-0.156 * * *$ & $-0.048^{*}$ & $0.200 * * *$ & $0.135^{* * *}$ & -0.005 & $0.369 * * *$ & $0.313 * * *$ & 0.060 \\
\hline & $(0.024)$ & $(0.040)$ & $(0.028)$ & $(0.022)$ & $(0.043)$ & $(0.048)$ & $(0.031)$ & $(0.033)$ & $(0.039)$ \\
\hline \multirow[t]{2}{*}{ Constant } & $-2.095^{* * *}$ & $-4.488^{* * *}$ & $-6.308^{* * *}$ & $-2.797 * * *$ & $-4.437^{* * *}$ & -0.907 & $0.635^{*}$ & -0.557 & $3.573 * * *$ \\
\hline & $(0.280)$ & (0.596) & $(0.608)$ & (0.439) & $(1.046)$ & (0.919) & $(0.357)$ & $(0.879)$ & $(1.365)$ \\
\hline Observations & 1,821 & 1,625 & 1,433 & 1,815 & 1,619 & 1,425 & 1,809 & 1,613 & 1,419 \\
\hline Number of groups & 49 & 48 & 48 & 49 & 49 & 48 & 49 & 49 & 48 \\
\hline Within R-squared & 0.553 & 0.606 & 0.617 & 0.556 & 0.580 & 0.565 & 0.615 & 0.599 & 0.575 \\
\hline
\end{tabular}

Annex Table 5: Combining Internal and External Imbalances, Additional Controls

\begin{tabular}{|c|c|c|c|c|c|c|c|c|c|}
\hline \multirow[b]{3}{*}{ VARIABLES } & $(1)$ & (2) & (3) & (4) & $(5)$ & (6) & (7) & $(8)$ & (9) \\
\hline & \multicolumn{3}{|c|}{ CA } & \multicolumn{3}{|c|}{ Saving } & \multicolumn{3}{|c|}{ Investment } \\
\hline & 1 year & 5 years & 9 years & 1 year & 5 years & 9 years & 1 year & 5 years & 9 years \\
\hline \multirow[t]{2}{*}{ Recession } & $-1.652^{* * *}$ & $-2.129 * * *$ & $-1.500 * * *$ & $-1.607^{* * *}$ & $-1.630 * * *$ & $-1.809 * * *$ & 0.064 & 0.456 & 0.044 \\
\hline & $(0.378)$ & $(0.324)$ & $(0.303)$ & $(0.374)$ & $(0.213)$ & $(0.380)$ & $(0.273)$ & $(0.329)$ & $(0.328)$ \\
\hline \multirow[t]{2}{*}{ Recession*credit boom } & -0.347 & $0.887^{* *}$ & $2.736^{* * *}$ & $-2.660 * * *$ & $-3.154 * * *$ & -0.303 & $-1.721 * * *$ & $-3.414 * * *$ & $-2.969 * * *$ \\
\hline & $(0.498)$ & $(0.399)$ & $(0.628)$ & $(0.458)$ & $(0.719)$ & $(0.424)$ & $(0.588)$ & $(0.541)$ & $(0.453)$ \\
\hline \multirow[t]{2}{*}{ Recession*high debt } & -0.194 & $1.511^{* * *}$ & $0.973 * *$ & $0.908^{* * *}$ & $1.053 * * *$ & $1.518^{* * *}$ & $1.160^{* * *}$ & -0.328 & -0.077 \\
\hline & $(0.325)$ & $(0.406)$ & $(0.482)$ & $(0.231)$ & $(0.341)$ & $(0.479)$ & $(0.163)$ & $(0.254)$ & (0.447) \\
\hline \multirow[t]{2}{*}{ Recession*CA deficit } & $1.791 * * *$ & $2.132 * * *$ & $2.258^{* * *}$ & $1.497^{* * *}$ & $2.299 * * *$ & $2.075^{* * *}$ & $-0.698^{* *}$ & -0.124 & -0.596 \\
\hline & $(0.408)$ & $(0.391)$ & $(0.431)$ & $(0.363)$ & $(0.344)$ & $(0.375)$ & $(0.300)$ & $(0.558)$ & (0.549) \\
\hline \multirow[t]{2}{*}{ Recession*high external debt } & $1.187 * * *$ & $1.236 * * *$ & $1.281 * * *$ & $0.722^{* *}$ & $0.935^{* *}$ & 0.069 & $-0.428 * * *$ & -0.114 & -0.430 \\
\hline & $(0.265)$ & $(0.475)$ & $(0.423)$ & $(0.314)$ & $(0.364)$ & $(0.633)$ & $(0.157)$ & $(0.577)$ & $(0.552)$ \\
\hline \multirow[t]{2}{*}{$\Delta$ Exchange rate } & $-0.020^{* *}$ & -0.000 & $0.030^{* * *}$ & $-0.024 * * *$ & -0.012 & 0.018 & 0.006 & 0.004 & 0.009 \\
\hline & $(0.010)$ & $(0.015)$ & $(0.010)$ & $(0.004)$ & $(0.013)$ & $(0.015)$ & $(0.009)$ & $(0.015)$ & $(0.014)$ \\
\hline \multirow[t]{2}{*}{ Openness } & $0.036 * * *$ & $0.051^{* * *}$ & $0.032^{* * *}$ & $0.035^{* * *}$ & $0.057 * * *$ & 0.024 & 0.002 & 0.013 & 0.009 \\
\hline & $(0.005)$ & $(0.010)$ & $(0.011)$ & $(0.006)$ & $(0.012)$ & $(0.020)$ & $(0.003)$ & $(0.012)$ & $(0.014)$ \\
\hline \multirow[t]{2}{*}{ Relative Growth } & $-0.317^{* * *}$ & $-0.235 * * *$ & -0.068 & $0.120^{* * *}$ & 0.009 & -0.117 & $0.364 * * *$ & $0.222^{* * *}$ & -0.058 \\
\hline & $(0.040)$ & $(0.058)$ & $(0.070)$ & $(0.036)$ & $(0.065)$ & $(0.104)$ & $(0.046)$ & $(0.045)$ & $(0.061)$ \\
\hline \multirow[t]{2}{*}{ Constant } & $-2.591 * * *$ & $-5.176 * * *$ & 0.000 & $-3.140 * * *$ & $-4.317^{* * *}$ & 0.000 & -0.195 & -0.877 & 0.000 \\
\hline & $(0.475)$ & $(0.873)$ & $(0.000)$ & $(0.417)$ & $(0.855)$ & $(0.000)$ & (0.394) & $(0.983)$ & $(0.000)$ \\
\hline Observations & 1,324 & 1,227 & 1,037 & 1,319 & 1,222 & 1,030 & 1,322 & 1,225 & 1,033 \\
\hline Number of groups & 49 & 48 & 48 & 49 & 49 & 48 & 49 & 49 & 48 \\
\hline Within R-squared & 0.569 & 0.606 & 0.643 & 0.579 & 0.609 & 0.605 & 0.690 & 0.631 & 0.621 \\
\hline
\end{tabular}

Notes: Standard errors in parentheses. Variables included in the es timation but not shown are first and second lags of Recession and the dependent variable, the vulnerabilities, and time and country fixed effects.

*** $\mathrm{p}<0.01,{ }^{* *} \mathrm{p}<0.05,{ }^{*} \mathrm{p}<0.1$ 
Annex Table 6: Synchronization, and Internal and External Imbalances

\begin{tabular}{|c|c|c|c|c|c|c|c|c|c|}
\hline \multirow[b]{3}{*}{ VARIABLES } & \multirow{2}{*}{\multicolumn{3}{|c|}{$\frac{(2)}{C A}$}} & (4) & (5) & (6) & (7) & (8) & (9) \\
\hline & & & & \multicolumn{3}{|c|}{ Saving } & \multicolumn{3}{|c|}{ Investment } \\
\hline & 1 year & 5 years & 9 years & 1 year & 5 years & 9 years & 1 year & 5 years & 9 years \\
\hline \multirow[t]{2}{*}{ Recession } & 0.615 & -0.445 & 0.373 & $-1.172 * * *$ & $-1.251 * *$ & $-2.076 * *$ & $-1.963 * * *$ & -0.639 & $-1.664 * * *$ \\
\hline & $(0.492)$ & $(0.525)$ & $(0.527)$ & $(0.452)$ & $(0.560)$ & $(0.835)$ & $(0.262)$ & $(0.511)$ & $(0.553)$ \\
\hline \multirow[t]{2}{*}{ Recession*credit boom } & 0.359 & $1.355^{* * *}$ & $3.028^{* * *}$ & $-2.605^{* * *}$ & $-3.355^{* * *}$ & -0.179 & $-2.359 * * *$ & $-3.663^{* * *}$ & $-2.819^{* * *}$ \\
\hline & $(0.483)$ & $(0.416)$ & $(0.534)$ & $(0.453)$ & $(0.794)$ & (0.489) & $(0.513)$ & $(0.557)$ & $(0.431)$ \\
\hline \multirow[t]{2}{*}{ Recession*high debt } & -0.433 & $1.171^{* * *}$ & 0.791 & $0.701 * * *$ & $0.630 * *$ & $1.494 * * *$ & $1.222 * * *$ & -0.159 & 0.125 \\
\hline & $(0.284)$ & $(0.338)$ & $(0.481)$ & $(0.229)$ & $(0.321)$ & $(0.502)$ & $(0.163)$ & $(0.244)$ & $(0.443)$ \\
\hline \multirow[t]{2}{*}{ Recession*CA deficit } & $1.636^{* * *}$ & $2.127^{* * *}$ & $1.345^{* * *}$ & $1.094^{* * *}$ & $2.228^{* * *}$ & $1.896^{* * *}$ & $-0.676 * * *$ & -0.354 & 0.052 \\
\hline & $(0.408)$ & $(0.372)$ & $(0.509)$ & $(0.373)$ & $(0.345)$ & $(0.331)$ & $(0.249)$ & $(0.550)$ & $(0.592)$ \\
\hline \multirow[t]{2}{*}{ Recession*high external debt } & $0.962^{* * *}$ & $1.134 * * *$ & $1.134^{* * *}$ & $0.558^{*}$ & $1.182^{* * *}$ & 0.622 & -0.275 & -0.133 & -0.443 \\
\hline & $(0.276)$ & $(0.439)$ & $(0.344)$ & $(0.297)$ & $(0.342)$ & $(0.617)$ & $(0.175)$ & $(0.546)$ & $(0.490)$ \\
\hline \multirow{2}{*}{ Recession*global 25} & $-1.416^{* * *}$ & $-1.280^{*}$ & $-1.963^{* * *}$ & $-1.007 * * *$ & -0.264 & 1.310 & $1.055^{* * *}$ & $0.707^{*}$ & $2.617^{* * *}$ \\
\hline & $(0.353)$ & $(0.667)$ & $(0.639)$ & $(0.300)$ & $(0.787)$ & $(1.008)$ & $(0.238)$ & $(0.428)$ & $(0.484)$ \\
\hline \multirow[t]{2}{*}{ Constant } & $-0.811^{* * *}$ & $-3.429 * * *$ & $-3.535^{* * *}$ & $-0.702 * * *$ & $-2.366^{* * *}$ & $-1.545^{* * *}$ & $1.428^{* * *}$ & 0.244 & 0.377 \\
\hline & $(0.168)$ & $(0.331)$ & $(0.244)$ & $(0.150)$ & $(0.209)$ & $(0.268)$ & $(0.209)$ & $(0.320)$ & $(0.273)$ \\
\hline Observations & 1,480 & 1,383 & 1,193 & 1,441 & 1,344 & 1,152 & 1,440 & 1,343 & 1,151 \\
\hline Number of groups & 49 & 48 & 48 & 49 & 49 & 48 & 49 & 49 & 48 \\
\hline Within R-squared & 0.556 & 0.593 & 0.640 & 0.576 & 0.598 & 0.587 & 0.678 & 0.619 & 0.631 \\
\hline
\end{tabular}

